\title{
Irrigation Customer Survey Procedures and Results- Detailed Analysis
}
M. P. Hattrup
R. O. Weijo
B. J. Harrer, Project Manager

\section{August 1987}

\section{Prepared for}

the Bonneville Power Administration under a Related Services Agreement with the U.S. Department of Energy under Contract DE-AC06-76RLO 1830

Pacific Northwest Laboratory Operated for the U.S. Department of Energy by Battelle Memorial Institute 


\section{DISCLAIMER}

This report was prepared as an account of work sponsored by an agency of the United States Government. Neither the United States Government nor any agency thereof, nor Battelle Memorial Institute, nor any of their employees, makes any warranty, expressed or implied, or assumes any legal liability or responsibility for the accuracy, completeness, or usefulness of any information, apparatus, product, or process disclosed, or represents that its use would not infringe privately owned rights. Reference herein to any specific commercial product, process, or service by trade name, trademark, manufacturer, or otherwise, does not necessarily constitute or imply its endorsement, recornmendation, or favoring by the United States Government of any agency thereof, or Battelle Memorial Institute. The views and opinions of authors expressed herein do not necessarly state or reflect those of the United States Government or any agency thereof, or Battelle Mernorial Institute.

\section{PACIFIC NORTHWEST LABORATORY operated by \\ BATTELLE MEMORIAL INSTITUTE \\ for the \\ UNITED STATES DEPARTMENT OF ENERGY under Contract DE-AC06-76RLO 1830}

\begin{tabular}{|c|c|}
\hline \multicolumn{2}{|c|}{ Printed in the United States of America } \\
\hline \multirow{2}{*}{\multicolumn{2}{|c|}{$\begin{array}{l}\text { Available from } \\
\text { National Technical Information Service }\end{array}$}} \\
\hline & \\
\hline \multirow{3}{*}{\multicolumn{2}{|c|}{$\begin{array}{c}\text { United States Department of Commerce } \\
5285 \text { Port Royal Road } \\
\text { Springfield, Virginia } 22161\end{array}$}} \\
\hline & \\
\hline & \\
\hline \multirow{2}{*}{\multicolumn{2}{|c|}{$\begin{array}{l}\text { NTIS Price Codes } \\
\text { Microfiche A01 }\end{array}$}} \\
\hline & \\
\hline \multicolumn{2}{|c|}{ Printed Copy } \\
\hline & Price \\
\hline Pages & Codes \\
\hline 001-025 & $\mathrm{A} 02$ \\
\hline $026-050$ & $\mathrm{~A} 03$ \\
\hline 051-075 & $\mathrm{A} 04$ \\
\hline $076-100$ & A05 \\
\hline $101-125$ & $\mathrm{~A} 06$ \\
\hline $126-150$ & A07 \\
\hline $151-175$ & $\mathrm{~A} 08$ \\
\hline $176-200$ & A09 \\
\hline $201-225$ & A010 \\
\hline $226-250$ & A011 \\
\hline $251-275$ & A012 \\
\hline $276-300$ & A013 \\
\hline
\end{tabular}


IRRIGATION CUSTOMER SURVEY PROCEDURES AND RESULTS -

DETAILED ANALYSIS

B. J. Harrer, Project Manager

M. P. Hattrup

R. 0 . Weijo

August 1987

Prepared for the Bonneville Power Administration under a Related Services Agreement with the U.S. Department of Energy under Contract DE-AC06-76RLO 1830

Pacific Northwest Laboratory Richland, Washington 99352 


\section{EXECUTIVE SUMMARY}

This report presents the results of analyses of data obtained from telephone and in-person survey of irrigators in the Pacific Northwest region. These analyses were requested by the Bonneville Power Administration (Bonneville) in association with needs for information pertaining to various aspects of Bonneville activities in the irrigation sector, including conservation programs and load forecasting.

The telephone survey involved approximately 1250 completed responses from irrigators selected from throughout the Northwest. The in-person survey, which is documented in this report, involved approximately 250 completed responses from irrigators within public utility districts that obtain electricity for serving irrigation loads from Bonneville. The questions contained in the inperson survey instrument were designed to obtain more detailed information than could be obtained in the telephone survey. The questions analyzed in this study were selected through consultations with Bonneville staff.

The results of the analyses conducted in this study revealed that information sources, such as Bonneville's Stage I irrigation system audit program, have been a major factor in influencing adoption of the conservation technology of low-pressure irrigation on center-pivot systems. In addition, study results indicate that Bonneville has generally been successful in targeting its stage I program to the medium-sized farmers that it regards as its primary target market. However, because the Stage I program has primarily involved medium-sized farmers, the estimated energy savings from the program should be extrapolated to the region on a conservative basis because these savings are likely to be lower among both larger and smaller farmers.

The market penetration of the Stage I program was estimated in this study to range from 1 percent in Grant County PUD to 56 percent in Lincoln Electric Coop among utilities participating in the Stage I program. Approximately 1,600 irrigation system inspections are estimated to have been performed in association with the Stage I program at the end of 1986 . Only a small proportion of irrigators having Stage I inspections decided to participate in the Stage II 
program, and the primary factor determining Stage II participation was found to be the utility in which the irrigator was located.

The study results indicate that financing generally does not constitute a significant barrier to conservation measure adoption by irrigators relative to other factors, such as informational barriers. In-person survey responses generally revealed that if the cost-effectiveness of conservation investments could be sufficiently demonstrated, irrigators were generaliy able to obtain required financing from either internal farm sources or traditional farm lending sources (banks, credit associations, etc.).

Testimonials from other farmers and other forms of personal interactions were found to be the most effective means of demonstrating the benefits of conservation measures to irrigators. Irrigators that had taken conservation actions generally indicated that they were happy with the results of their actions, irrespective of whether the actions were taken within or outside of the auspices of Bonneville programs.

Although the conservation measure of low-pressure irrigation on centerpivot systems is relatively well known among iprigators, it appears that information pertaining to other types of measures is sti11 needed. Approximately 40 percent of in-person survey respondents indicated that they were not aware or acquainted with the conservation measures of low-pressure on handmove/ sideroll systems and systematic scheduling methods.

Reducing energy costs was found to be of significant concern to irrigators relative to other actions that they could undertake to improve financial returns, such as improving marketing or reducing labor costs. The only action ranked higher in importance than reducjng energy costs was maintaining or increasing crop yields.

The results of this study revealed that the majority of the relatively small number of irrigators reporting that they had developed more land for irrigation between 1980 and 1985 are large farmers located in either Southern Oregon or Southern Idaho. Conversely, the majority of irrigators reporting decreases in irrigated acres between 1980 and 1985 are located in either the Columbia Basin or North-Central Oregon. A strong positive relationship between 
reported decreases in irrigated acres and increasing pumping lifts was found, with approximately two-thirds of those respondents reporting acreage decreases having average pumping lifts in excess of 100 feet.

Although concerns have often been expressed about widespread conversions of irrigated farm land to dryland farming, the survey responses revealed that such conversions are not likely to affect the majority of irrigated acres. Approximately 44\% of in-person survey respondents felt that the profitability of irrigated farming was higher than dryland farming, while oniy $22 \%$ believed the profitability of irrigated farming was lower than that of dryland farming.

Based on the survey responses, it appears the crop mixes on irrigated land are likely to shift away from commodity-type crops (wheat, corn, barley) towards more specialty-type crops (orchard, potatoes, vegetables, etc.). Most respondents felt that the future profitability of specialty crops would be high relative to commodity crops, and this belief was reflected in their future cropping plans, which were directed towards increasing specialty crop acres and decreasing commodity crop acres. 


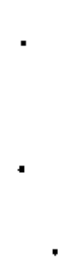

. 


\section{CONTENTS}

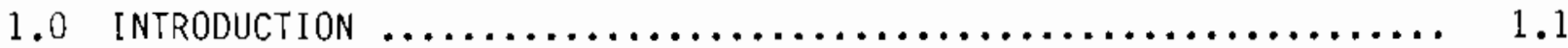

2.0 CONCLUSiONS AND RECOMMENDATIONS $\ldots \ldots \ldots \ldots \ldots \ldots \ldots \ldots \ldots \ldots, 2.1$

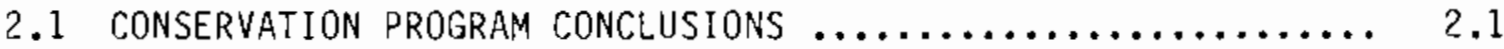

2.2 LOAD FORECASTING RESULTS $\ldots \ldots \ldots \ldots \ldots \ldots \ldots \ldots \ldots \ldots \ldots \ldots \ldots \ldots \ldots \ldots . .4$

2.3 RECOMMENDATIONS $\ldots \ldots \ldots \ldots \ldots \ldots \ldots \ldots \ldots \ldots \ldots \ldots \ldots \ldots \ldots \ldots \ldots \ldots \ldots, 2.5$

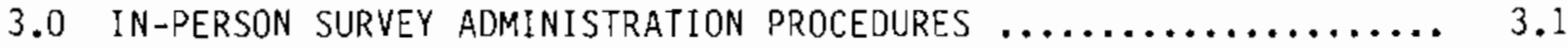

3.1 QuestionNAIRE DESIGN $\ldots \ldots \ldots \ldots \ldots \ldots \ldots \ldots \ldots \ldots \ldots \ldots \ldots \ldots \ldots \ldots, 3.1$

3.2 SAMPLE SELECTION $\ldots \ldots \ldots \ldots \ldots \ldots \ldots \ldots \ldots \ldots \ldots \ldots \ldots \ldots \ldots \ldots \ldots \ldots, 3.1$

3.3 DATA COLLECTION $\ldots \ldots \ldots \ldots \ldots \ldots \ldots \ldots \ldots \ldots \ldots \ldots \ldots \ldots \ldots \ldots \ldots \ldots, 3.2$

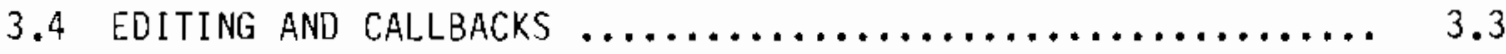

3.5 DATA ENTRY AND PROCESSING $\ldots \ldots \ldots \ldots \ldots \ldots \ldots \ldots \ldots \ldots \ldots \ldots \ldots \ldots \ldots \ldots \ldots .7$

3.6 DATA FORMAT AND CODES $\ldots \ldots \ldots \ldots \ldots \ldots \ldots \ldots \ldots \ldots \ldots \ldots \ldots \ldots \ldots \ldots \ldots, 3.8$

3.6.1 Data Format Convention $\ldots \ldots \ldots \ldots \ldots \ldots \ldots \ldots \ldots \ldots . .9 \ldots \ldots$

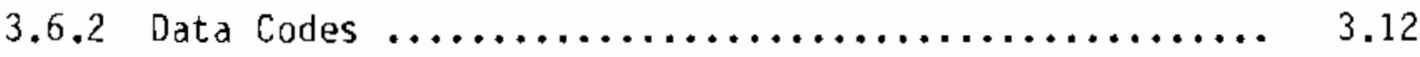

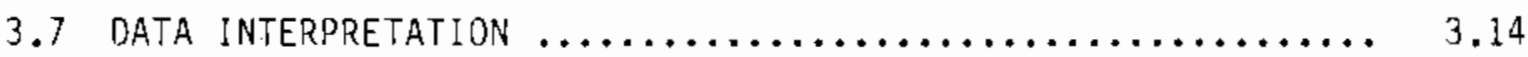

4.0 SPECIFIC QUESTIONS AND ANSWERS FROM SURVEY RESULTS $\ldots \ldots \ldots \ldots \ldots . . .1$

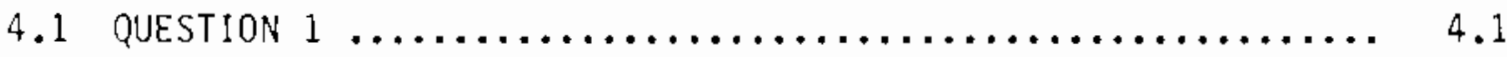

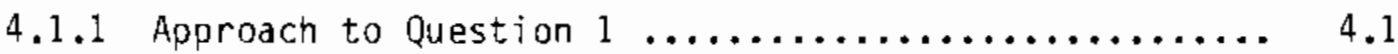

4.1 .2 Resutts $\ldots \ldots \ldots \ldots \ldots \ldots \ldots \ldots \ldots \ldots \ldots \ldots \ldots \ldots \ldots \ldots \ldots \ldots, 4.7$

4.2 QUESTION $2 \ldots \ldots \ldots \ldots \ldots \ldots \ldots \ldots \ldots \ldots \ldots \ldots \ldots \ldots \ldots \ldots \ldots \ldots, 4.14$

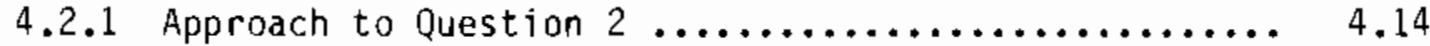

4.2 .2 Results $\ldots \ldots \ldots \ldots \ldots \ldots \ldots \ldots \ldots \ldots \ldots \ldots \ldots \ldots \ldots \ldots \ldots, 4.15$

4.3 QUESTION $3 \ldots \ldots \ldots \ldots \ldots \ldots \ldots \ldots \ldots \ldots \ldots \ldots \ldots \ldots \ldots \ldots \ldots \ldots \ldots, 4.18$

4.3.1 Approach to Question $3 \ldots \ldots \ldots \ldots \ldots \ldots \ldots \ldots \ldots . . .6 .18$ 


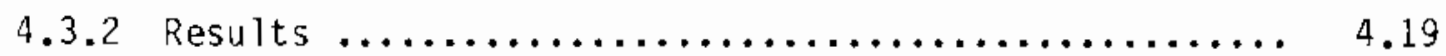

4.4 QUESTION $4 \ldots \ldots \ldots \ldots \ldots \ldots \ldots \ldots \ldots \ldots \ldots \ldots \ldots \ldots \ldots \ldots \ldots \ldots, 4.22$

4.4.1 Approach to Question $4 \ldots \ldots \ldots \ldots \ldots \ldots \ldots \ldots \ldots, 4.23$

4.4 .2 Resuits $\ldots \ldots \ldots \ldots \ldots \ldots \ldots \ldots \ldots \ldots \ldots \ldots \ldots \ldots \ldots \ldots \ldots \ldots, 4.23$

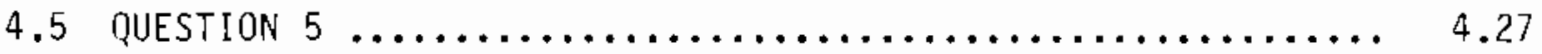

4.5 .1 Approach to Question $5 \ldots \ldots \ldots \ldots \ldots \ldots \ldots \ldots \ldots, 4.27$

4.5 .2 Results $\ldots \ldots \ldots \ldots \ldots \ldots \ldots \ldots \ldots \ldots \ldots \ldots \ldots \ldots \ldots \ldots \ldots \ldots, 4.27$

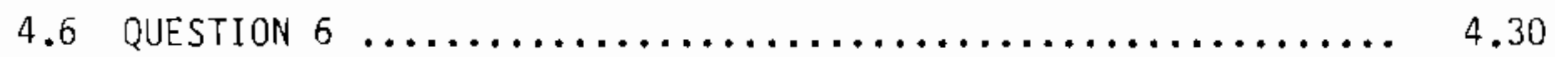

4.6 .1 APPROACH TO QUESTION $6 \ldots \ldots \ldots \ldots \ldots \ldots \ldots \ldots \ldots ., 4.30$

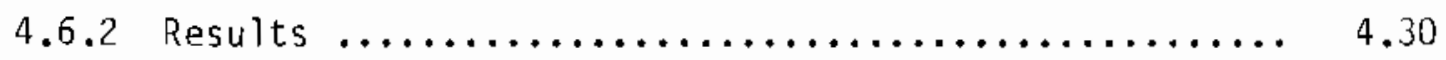

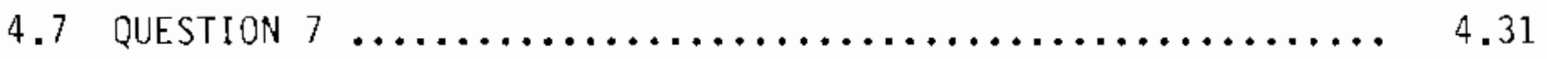

4.7.1 Approach to Question $7 \ldots \ldots \ldots \ldots \ldots \ldots \ldots \ldots . . .6 . .31$

4.7 .2 Results $\ldots \ldots \ldots \ldots \ldots \ldots \ldots \ldots \ldots \ldots \ldots \ldots \ldots \ldots \ldots \ldots \ldots \ldots, 4.32$

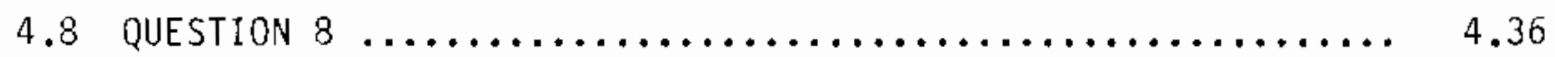

4.8.1 Approach to Question $8 \ldots \ldots \ldots \ldots \ldots \ldots \ldots \ldots \ldots, 4.36$

4.8 .2 Results $\ldots \ldots \ldots \ldots \ldots \ldots \ldots \ldots \ldots \ldots \ldots \ldots \ldots \ldots \ldots \ldots \ldots \ldots \ldots, 4.36$

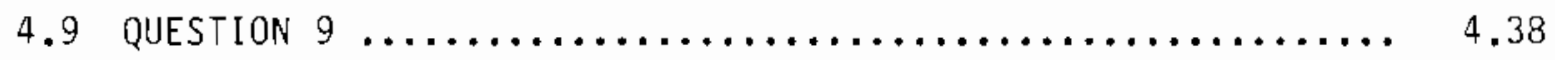

4.9.1 Approach to Question $9 \ldots \ldots \ldots \ldots \ldots \ldots \ldots \ldots . . .6 .38$

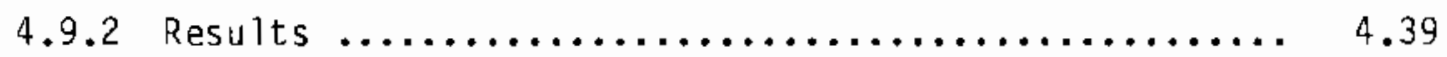

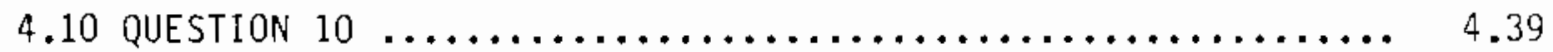

4.10 .1 Approach to Question $10 \ldots \ldots \ldots \ldots \ldots \ldots \ldots \ldots \ldots, 4.40$

4.10 .2 Results $\ldots \ldots \ldots \ldots \ldots \ldots \ldots \ldots \ldots \ldots \ldots \ldots \ldots, \quad 4.40$

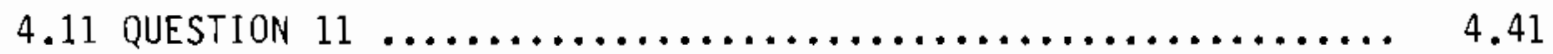

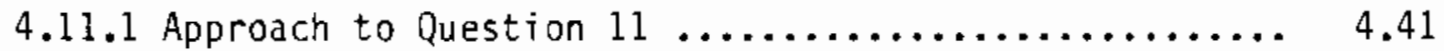

4.11 .2 Results $\ldots \ldots \ldots \ldots \ldots \ldots \ldots \ldots \ldots \ldots \ldots \ldots \ldots, 4.42$ 


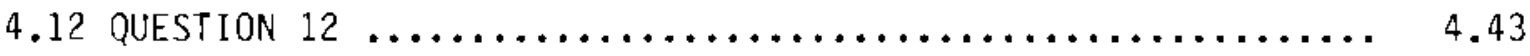

4.12.1 Approach to Question $12 \ldots \ldots \ldots \ldots \ldots \ldots \ldots . . .4 .43$

4.12 .2 Results .................................. 4.44

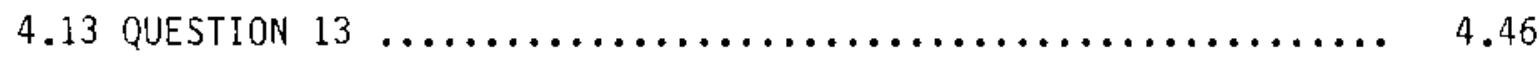

4.13.1 Approach to Question $13 \ldots \ldots \ldots \ldots \ldots \ldots \ldots \ldots . . .6 .46$

4.13 .2 Results $\ldots \ldots \ldots \ldots \ldots \ldots \ldots \ldots \ldots \ldots \ldots \ldots \ldots \ldots \ldots, 4.46$

4.14 QUESTION $14 \ldots \ldots \ldots \ldots \ldots \ldots \ldots \ldots \ldots \ldots \ldots \ldots \ldots \ldots \ldots \ldots \ldots \ldots, 4.48$

4.14.1 Approach to Question $14 \ldots \ldots \ldots \ldots \ldots \ldots \ldots \ldots . . .4 .48$

4.14 .2 Results $\ldots \ldots \ldots \ldots \ldots \ldots \ldots \ldots \ldots \ldots \ldots \ldots \ldots \ldots, 4.50$

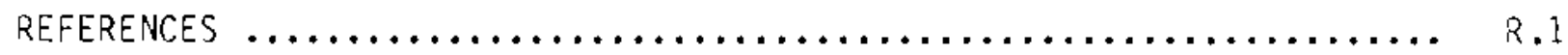

APPENDIX A - GUIDELINES ANO DECISION RULES FOR EDITING AND

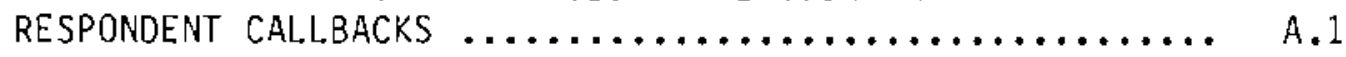

APPENDIX B - IN-PERSON SURVEY QUESTIONNAIRE WITH DATA FORMAT CONVENTIONS 


\section{TABLES}

1.1 Final List of Issues for Additional Survey Analysis $\ldots \ldots \ldots \ldots . .2$

1.2 Breakdown of Irrigation Customer Survey U-Strata $\ldots \ldots \ldots \ldots \ldots . . .4$

3.1 Summary of Completed In-Person Survey Interviews $\ldots \ldots \ldots \ldots \ldots . . .4$

3.2 Added Data Codes--Decision Rule: At Least 5\% of Responses to the Particular Question Fall into the Particular Category ....... 3.13

4.1 Number of Irrigators Reporting First-Year Adoption of Low-Pressure Irrigation on Center-Pivot Systems $\ldots \ldots \ldots \ldots \ldots . . .2$

4.2 Factors Selected for Use as Independent Variables in a Discriminant Analysis Explaining Adoption Versus Non-

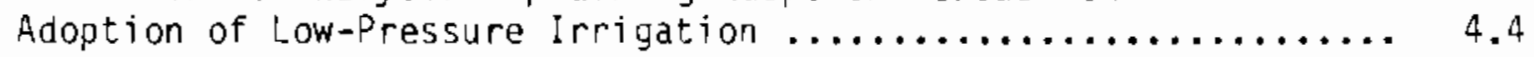

4.3 Overall Discriminant Function Results for Low-Pressure

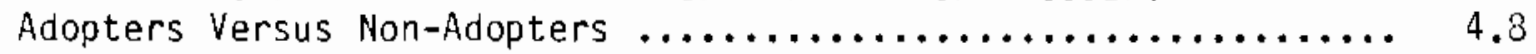

4.4 Summary of Results for Variales Incorporated in the

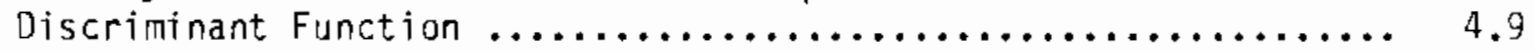

4.5 Informational Variable Definitions Derived from Factor

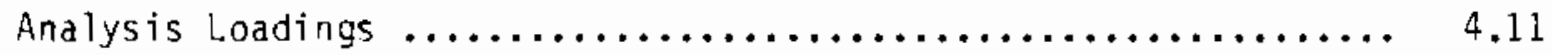

4.6 Overal1 Discriminant Function Results for Low-Pressure Adopters Versus non-Adopters Using Redefined Informational Variables ......................................... 4.12

4.7 Suminary of Results for Redefined Variabies Incorporated in

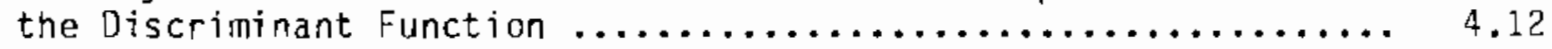

4.8 Percentage of Conservation measure Adopters Who First Learned of the Possibility of Installing Conservation Measures from

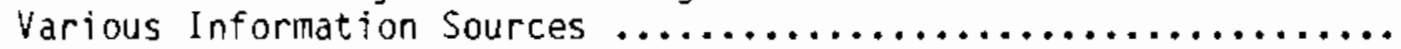

4.9 Percentage of Conservation measure Adopters Who Indicated They Were Convinced to Adopt Conservation Measures by

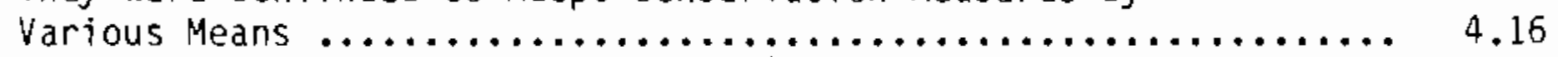

4.10 Initial Major Concerns of Conservation Measure Adopters ....... 4.17

4.11 Sources of Financing for Irrigator Investments in Conservation

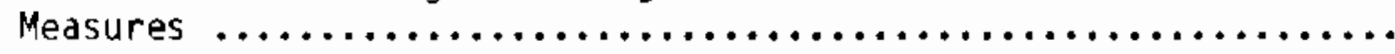

4.12 Perceived Difficulty of obtaining Financing for Conservation Measure Purchase and Installation 
4.13 Rated Importance of Various Factors in Limiting Conservation Investments by Non-Adopters of Conservation Measures

4.14 Percentages on In-Person Survey Respondents Who Were Aware of Various Methods of Reducing Energy Used in Irrigation

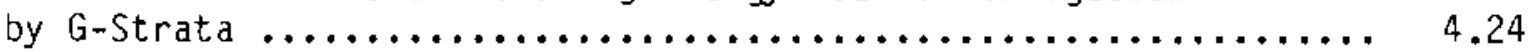

4.15 Percentages of In-Person Survey Respondents Who Were Aware of Various Methods of Energy Used in Irrigation by U-Strata ....... 4.25

4.16 Number and Percentage of Conservation measure Non-Adopters Who Could be Convinced to Try Conservation Measures by

4.17 Relative Importance of Energy Costs and Other Factors to Irrigators

4.18 Factor "Importance" Ratings by G-Stratum $\ldots \ldots \ldots \ldots \ldots \ldots \ldots \ldots .28$

4.19 Factor "Importance" Rating by U-Stratum ................... 4.29

4.20 Percentages of Conservation Measure Adopters Expressing

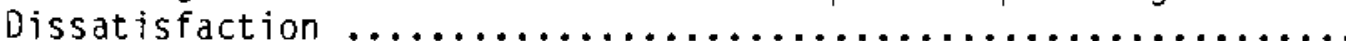

4.21 Frequency Distribution of Crop Types by Stage I and Non-Stage I

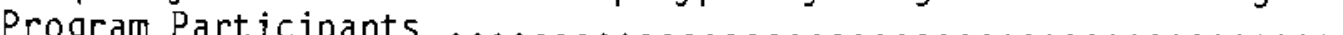

4.22 Frequency Distributions and Means of Acres Under Irrigation by Stage I and Non-Stage I Program Participants ..................

4.23 Estimated Market Penetration of Stage I Program for Public Utilities With Loads Exceeding 30,000 MWh or With Reported

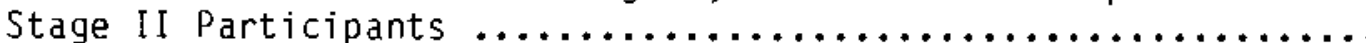

4.24 Frequency Distribution of Crop Types by Stage II and Stage

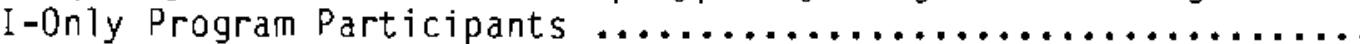

4.25 Frequency Distributions and Means of Acres Under Irrigation by Stage II and Stage $1-0$ niy Program Participants .............. 4.37

4.26 Estimated Penetration of Stage II Program at the End of $1984 \ldots \ldots 4.38$

4.27 Frequency Distribution of Dissatisfaction with Systematic

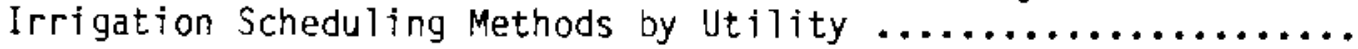

4.28 Frequency Distribution of Crops Grown by Adopters of Low-Pressure on Handmove/Siderol? Systems

4.29 Frequencies of Respondents Reporting That They "Converted/ Developed More Land" Between 1980 and 1985 by Utility 
4.30 Frequencies of Respondents Reporting That They "Converted/ Developed More Land" Between 1980 and 1985 by G-Strata ........ 4.43

4.31 Frequencies of Respondents Reporting That They "Converted/ Developed More Land" Between 1980 and 1985 by U-Strata ........ 4.43

4.32 Frequency Distribution of Irrigators Reporting Decreased in

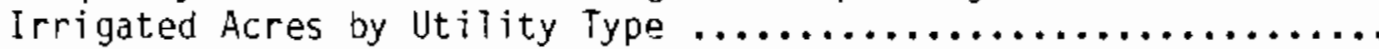

4.33 Frequency Distribution of Irrigators Reporting Decreases in

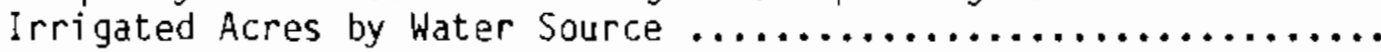

4.34 Frequency Distribution of Irrigators Reporting Decreases in

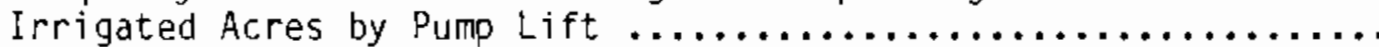

4.35 Frequency Distribution of Irrigators Reporting Decrease in

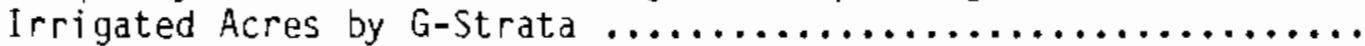

4.36 Frequency Distribution of Irrigators Reporting Decreases in

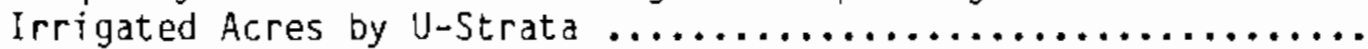

4.37 Views on Relative Profitability of Irrigated Farming .......... 4.47

4.38 Views on Relative Profitability of Irrigated Farming $\ldots . . . \ldots . .44 .47$

4.39 Expected Profitability of Crops Over the Time Horizons Used by Irrigators in Making Cropping and Investment Decisions ......... 4.50

4.40 Expected Profitability of Crops in Five Years ................ 4.50

4.41 Expected Percentage Change in Mean Irrigated Crop Acres Over the Next Five Years by G-Strata 


\subsection{INTRODUCTION}

In 1986, the Bonneville Power Administration (Bonneville) commissioned Pacific Northwest Laboratory (PNL) to design and manage a telephone survey involving approximately 1250 Pacific Northwest irrigators and a follow-up inperson survey of approximately 250 respondents. The purpose of these surveys was to obtain information that could potentially be used for a variety of purposes, including conservation planning, load forecasting and rate design. The need for the surveys was justified by the inadequacy of existing information pertaining to the characteristics of irrigated agricultural operations in the region and the importance of the irrigation sector as a summer load for the regional power system, particularly for selected rural utilities.

The major results of the celephone survey of irrigators were presented in a previous report (Harrer, et. al. 1987). However, no analyses of the inperson survey results were incorporated in the previous study. The purpose of this study is to provide such analyses, and, where appropriate, to perform additional analyses of the telephone survey resuits.

To focus the present study on those issues of most interest to Bonneville, a planning meeting was held between Bonneville and PNL staff in October, 1986. This meeting resulted in a draft list of issues that were submitted to Bonneville for further review. A final list of issues to be addressed in the study was then developed by PNL. This list is shown in Table 1.1, along with the areas of Bonneville that each issue appears to be most relevant to.

The remainder of this report describes the approaches used in addressing each of the issues identified in Table 1.1 and the results of the analysis of each selected issue. Documentation of the procedures used in designing, conducting, editing and formatting the in-person survey are also presented.

The report is organized into four chapters. The second chapter presents the major results and conclusions of the study. In Chapter 3.0, documentation on the administration of the in-person survey is presented. Analyses of each of the selected issues identified in Table 1.1 are presented in Chapter 4. 


\section{TABLE 1.1. Final List of Issues for Additional Survey Analysis}

1) How can the irrigation customer market be segmented in terms of adopters and non-adopters of energy-saving technologies and what are the relative importance of awareness, financing ability, attitudes towards new technology, participation in BPA prograins and other factors in determining adoption and non-adoption? [Primary Bonneville Areas - Conservation Programs, Program Evaluation]

2) How did those irrigators who have taken conservation actions in the last seven years first become aware of the possibility of undertaking such actions, what conditions were necessary to convince them to undertake such actions and what were their initial concerns about undertaking conservation actions? [Primary Bonneville AreasConservation Programs, Program Evaluation]

3) Where did irrigators adopting conservation measures obtain financing for measure purchase and installation, how difficult was it for them to obtain such financing, and how important are financing constraints in limiting conservation actions relative to other factors? [Primary Bonneville Areas - Conservation Programs, Program Evaluation]

4) How aware of the possibility of undertaking conservation actions are those irrigators who have not taken conservation actions, and what would be necessary to convince them to undertake conservation actions? [Primary Bonneville Areas - Conservation Programs, Program Evaluation]

5) What is the relative importance of reducing energy costs to irrigators? [Primary Bonneville Areas - Conservation Programs, Rates]

6) How satisfied are irrigators that have undertaken conservation actions on their own (i.e. outside of utility sponsored programs) with the energy savings and other benefits of these actions? [Primary Bonneville Programs, Area - Program Evaluation]

7) How do Phase I program participants compare to the general population of irrigators in terms of farm size, crop type and utility? [Primary Bonneville Areas - Program Evaluation, Conservation Planning]

8) How do Phase I and Phase II program participants compare to Phase I-only program participants in terms of farm size, crop type and utility? [Primary Bonneville Area - Program Evaluation]

9) Identify by utility those irrigators that expressed dissatisfaction with irrigation scheduling. [Primary Bonneville Area - Conservation Programs] 
TABLE 1.1. (contd)

10) Identify the crop types of irrigators reporting the use of lowpressure sprinklers on hand-move and sideroll systems. [Primary Bonneville Area - Conservation Programs]

11) Identify the G-Strata, U-Strata and utility of irrigators reporting that they had developed new land since 1980. [Primary Bonneville Area - Load Forecasting]

12) Identify the water source, pump lift, G-Strata, and U-Strata characteristics of farmers indicating that they had decreased sprinkler irrigated acres since 1980. [Primary Bonneville Area - Load Forecasting]

13) Determine whether farmers perceive irrigated framing to be relatively more profitable or less profitable than dryland farming. [Primary Bonneville Area - Load Forecasting]

14) Determine which crops farmers perceive are likely to be the most profitabie to grow in the future. [Primary Bonneville Area - Load Forecasting]

Much of the analysis presented in this report is separated on the basis of geographic area (G-Strata) and level of irrigation electrical usage (U-Strata). Definitions of the G-Strata defined for the study are shown in Figure 1.1, while definitions of U-Strata are shown in Table 1.2 . 


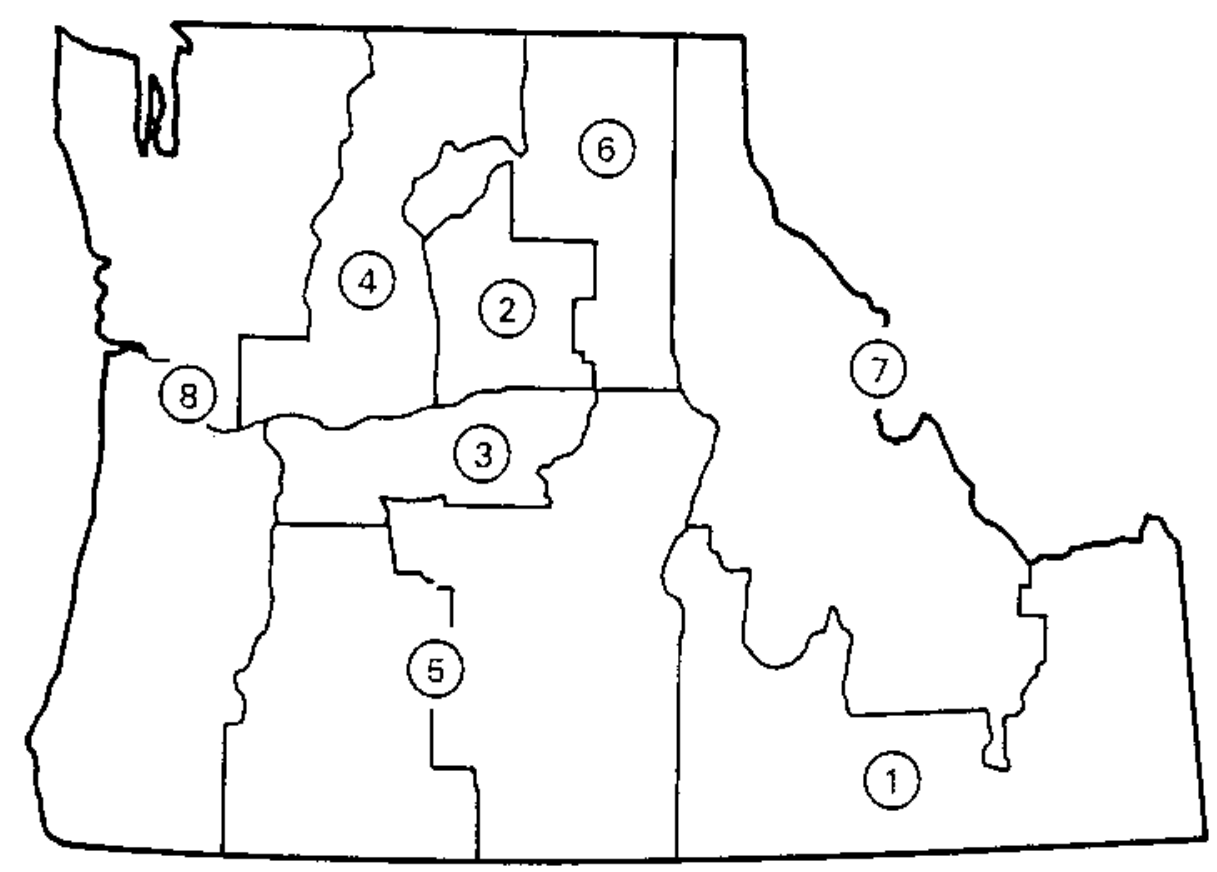

FIGURE 1.1. G-Strata Definitions

TABLE 1.2. Breakdown of Irrigation Customer Survey U-Strata

U-Strata

Number

6

5

4

3

2

1
General U-Strata Definition

All customers with 1984 irrigation loads >500 MWh

Al1 customers comprising $80 \%$ to $100 \%$ of remaining irrigation load in a utility within a G-Strata after load in U-Strata 6 was removed

All customers comprising $60 \%$ to $80 \%$ of remaining irrigation load in a utility within a G-Strata after load in U-Strata 6 was removed

A11 customers comprising $40 \%$ to $60 \%$ of remaining irrigation load in a utility within a G-Strata after load in U-Strata 6 was removed

A11 customers comprising $20 \%$ to $40 \%$ of remaining irrigation load in a utility within a G-Strata after load in U-Strata 6 was removed

A17 customers comprising $0 \%$ to $20 \%$ of remaining irrigation load in a utility within a G-Strata after load in U-Strata 6 was removed

(a) Utilities for which U-Strata were not defined based on figures shown in Table 1.2 are Idaho Power, Benton REA, and Ravalli Electric. 


\subsection{CONCLUSIONS AND RECOMMENDATIONS}

This study provides information on a number of issues associated with Bonneville activities in the irrigation sector of the Pacific Northwest. These activities may be broadly separated into conservation programs and load forecasting. The major conclusions arising from the study in these two areas are discussed below.

\subsection{CONSERVATION PROGRAM CONCLUSIONS}

A discriminant analysis was performed in an attempt to segment adopters of conservation technologies from non-adopters. Because of the large number of reported adopters of low-pressure irrigation on center-pivot systems, this technology was chosen as the basis for the discriminant analysis.

The discriminant analysis performed in this study produced statistically significant Chi-Square values at a 1 percent level of confidence. Thus, the analysis was able to separate adopters of low-pressure irrigation from nonadopters in a statistically significant fashion. Variables that proved to be statistically significant in positively influencing adoption of low-pressure included farm size, frequency in the use of information sources (particularly energy-related sources, such as utilities), location in North-Central Oregon, and a positive outlook regarding the future profitability of farming. These results indicate that information sources, such as Bonneville's Stage I inspection program, have been generally effective in influencing conservation technology adoption.

The majority of irrigators that had taken conservation actions since 1985 initially learned of the possibility of undertaking such actions from published magazines or irrigation equipment manufacturers. However, published magazines were generally ineffective in convincing irrigators to adopt conservation measures relative to more personal information sources, such as irrigation equip-

ment representatives and other farmers' experience. The major initial concerns about adopting conservation measures included run-off problems on low-pressure 
center-pivot systems, water coverage problems for low-pressure handmove/ sideroll systems, and concerns that the energy savings from using a systematic irrigation scheduling method would not justify its costs.

Based on the survey results, financing does not appear to be a major barrier to conservation measure adoption relative to other factors, such as concerns about inadequate crop irrigation and whether the savings from conservation measures would justify the costs. In addition, the majority of respondents reported in 1986 that obtaining financing for conservation measure investments was "not at all difficult." Most adopters of conservation measures reported that they obtained financing for their investments in conservation from either internal farm sources or traditional farm lending sources, such as farm credit associations.

Although familiarity of irrigators with the conservation measure of lowpressure on center-pivot systems was relatively widespread, knowledge of other types of measures can still be improved. Approximately 40 percent of in-person survey respondents indicated that they were unaware of the conservation measures of low-pressure on handmove/sideroll systems and systematic irrigation scheduling methods. In addition, an average of approximately $35 \%$ of respondents indicated that "nothing" could convince them to try these conservation measures. These results indicate that a significant amount of information dissemination and demonstrations of effectiveness will be necessary before these measures are adopted on a widespread basis.

Energy costs are a significant concern to irrigators relative to other factors. The action of "Reducing Energy Costs" was rated second in importance among five possible actions that irrigators could potentially take to improve their financial returns. The only action rated as being more important was maintaining and/or increasing crop yields. Actions rated as less important than reducing energy costs were reducing labor costs, reducing other production costs and increasing returns through better marketing.

Most irrigators that have undertaken conservation actions are satisfied with results of their actions, irrespective of whether they had participated in Bonneville's Stage I program. A significant finding concerning the Stage I program is that it has generally involved a higher proportion of farms that 
could be considered "medium" in size compared to non-Stage I program farms. The targeting of the Stage I program towards medium-sized farms has been a deliberate strategy of Bonneville that appears is being achieved. However, the higher proportion of medium-sized farms in the Stage I program indicates that the estimated energy savings from the program should be extrapolated to the entire region on a conservative basis because of the lower level of savings likely available on both smaller and larger farms.

Significant variation was found in the market penetration of the Stage I program in the various public utilities with irrigation loads in the region. The estimated market penetration of the Stage I program at the end of 1986 exceeded $20 \%$ of the total number of irrigation accounts in several utilities, including Lincoln Electric Coop, Ferry County PUD and Riverside Electric. However, several of the public utilities with major irrigation loads have chosen not to participate in the Stage I program and, consequently, the market penetration of the Stage I program among these utilities is zero. In addition, a number of utilities that are participants in the Stage I program, including Benton REA, Grant County PUD and Harney Electric Coop, have estimated market penetration rates of less than $5 \%$. The overall penetration of the Stage I program at the end of 1986 anong public utilities with significant irrigation loads is estimated to be $7.2 \%$ indicating that a large number of irrigation systems remain eligible for stage $I$ audits.

Significant variation was also found among utilities in the degree of participation in the Stage II program, given that a Stage I system inspection had been performed. Midstate Electric and Raft River had the highest degree of participation in the stage II program as of the end of 1985 with 71 and $50 \%$ of all 1984 and earlier Stage I program participants in their district choosing to participate in the Stage II program. Many utilities with reported Stage I inspections had no reported stage II program participants. Two of these utilities (Ravalli County Electric and Vigilante Electric) reported the completion of more than 50 Stage I audits by the end of 1984 without reporting a single Stage II program participant.

An analysis of reported dissatisfaction with systematic irrigation scheduling practices indicated that respondents expressing dissatisfaction with 
these practices were primarily located in Southern Idaho. Apparentiy, some type of systematic scheduling program was initiated in this area prior to 1985 that resulted in irrigator dissatisfaction. The primary types of crops irrigated with handmove/sideroll systems on which low-pressure had been installed were hay/alfalfa and wheat. Thus, it appear that adoption of this conservation technology is more likely on non water sensitive crops than on water sensitive crops (i.e. potatoes).

\subsection{LOAD FORECASTING RESULTS}

As reported in a previous study (Harrer, et. al. 1987), the telephone survey results indicated that irrigated acres in the Pacific Northwest increased by approximately $6 \%$ between 1980 and 1985 . However, it could not be determined directly from the survey results how much of the reported increase in irrigated acres represented new acreage development, as opposed to the trading of existing irrigated land among farmers. Of those reporting increases in irrigated acres since 1980, 11\% stated "converted/developed more 1and" as the reason for their increase. Most of the respondents reporting that they had "converted/developed more land" were found to be located in G-Strata 1 (Southern Idaho) and 5 (Southern Oregon). Most of these farmers were large farmers in U-Strata 5 and 6 .

Of those farmers reporting decreases in irrigated acres between 1980 and 1985, most were found to be located in G-Strata 1 (Southern Idaho), 2(Columbia Basin) and 3 (North-Central Oregon). A strong positive relationship between increasing pump lift and reported decreases in irrigated acres was noted. Approximately two-thirds of the respondents reporting decreases in irrigated acres also reported having average pumping lifts on their farms in excess of 100 feet. Thus, reported decreases in irrigated acres between 1980 and 1985 were primarily found on high lift, high water-demand acres.

Most of the survey respondents felt that the profitability of irrigated farming was higher than dryland farming. Only in G-Strata 6 (Northeastern washington) were there more respondents that felt the profitability of dryland farming was higher than that of irrigated framing. This result indicates that 
widespread conversions of irrigated acres to dryland farming are unlikely given the high investment costs associated with irrigated acres.

Most of the survey respondents felt that the expected future profitability of growing specialty crops like fruts and vegetables was higher than for commodity crops like wheat and corn. These views on profitability were reflected in future cropping mix plans, which indicated increases in acres of specialty crops and decreases in acres of commodity crops.

\subsection{RECOMMENDATIONS}

The results of these studies have several implications for Bonneville policy in the irrigation sector. The conclusion that frequency in the use informational sources, such as the Stage I program, have positively influenced the adoption of low-pressure on center-pivot indicates that such a program has beneficial impacts beyond those that can be directly measured through methods like participation in the Stage II conservation retrofit program. In addition, the finding that financing is not a particularly significant barrier to conservation measure adoption indicates that retrofit programs like the Stage II program are likely less important in assisting irrigators than informational programs like the Stage I program. In a time of limited Bonneville resources, it appears that priority should be placed on maintaining the Stage I program, even at the expense of the Stage II program.

Although adoption of the conservation measure of low-pressure on centerpivot systems has been rapid, awareness and adoption of other conservation measures is much less prevalent. Bonneville can still play a role in assisting irrigators by facilitating adoption of conservation measures like systematic irrigation scheduling. In addition, the conclusion that early adoption of conservation measures is positively related to farm size indicates that small and medium-sized irrigators can still be assisted by Bonneville programs. The finding that only $7.2 \%$ of the total number of irrigation systems served by public utilities in the Pacific Northwest with significant irrigation loads have been inspected under the Stage I program also indicates that Bonneville can stili provide a significant degree of assistance to irrigators through this program. 
Future shifts in irrigated crop mixes from commodity crops (wheat, corn, etc.) to specialty crops (orchard, vegetables, etc.) appear to be likely. Although widespread conversions of irrigated farmland to dryland farming do not appear likely, decreases in irrigated acres in high i ift, high water-demand areas do appear to be likely unless the relative profitability of irrigated agriculture in these areas improves. 


\subsection{IN-PERSON SURVEY ADMINISTRATION PROCEDURES}

The procedures used in developing the in-person survey questionnaire, administering the survey, data entry/processing, and the data format of the results are described in this chapter.

\subsection{QUESTIONNAIRE DESIGN}

The general purposes of the in-person survey were to:

1. validate data collected in the telephone portion of the research program

2. clarify issues arising from the telephone survey

3. provide additional data regarding usage of and interest in conservation programs among irrigators served by public utilities purchasing power from BPA.

The survey instrument was designed and drafted by PNL personnel with input from Bonneville and NEA. Market Trends' personnel revised PNL's draft to facjlitate data processing. Preliminary results from the telephone survey were used to identify particular question areas of investigation for the in-person survey. A copy of the questionnaire may be found in Appendix $B$ of this report.

\subsection{SAMPLE SELECTION}

The sample for the in-person survey was selected on the basis of two primary objectives that were identified in discussions with Bonneville staff:

1. emphasize irrigation customers served by utilities whose irrigation power demands are met by Bonneville

2. emphasize medium-size to large irrigation customers in geographic areas with high irrigation demands.

With these objectives in mind, a sample frame was defined using the following criteria: 
- population to be sampled is respondents to the telephone survey from public utilities that purchase power from Bonneville to serve irrigators and who indicated a willingness to participate in an in-person interview

- desired number of responses is 250

- G-Strata to be included in the sample are G-Strata 1 to 7

- U-Strata to be included in the sample are U-Strata 2 to 6 .

A sample was then selected from the sampling frame using the following methods:

- allocate the sample to the seven G-Strata proportional to the MWh irrigation load in each G-Stratum

- allocate each G-Stratum sample to the high U-Stratum proportional to the total Mwh irrigation load for users consuming at least 500 MWh in an irrigation season

- group the remaining U-Strata into two groups, with one group containing U-Strata 1 and 2 and the other group containing U-Strata 3 and 4

- allocate the remainder of the sample equally to each of the two groups

- randomly select the allocated sample in each U-Stratum from telephone survey respondents indicating a willingness to participate in in-person interviews.

\subsection{DATA COLLECTION}

The process of administering the in-person survey began with a meeting between NEA, Market Trends and PNL personnel to review the finalized questionnaire for the understanding of those that would be supervising and conducting the interviews. Telephone calls to arrange appointments with potential survey participants were also begun at this time.

Administration of the survey began in early february, 1986 with irrigators in G-Strata 2 (Columbia Basin), 3 (North-Central Oregon) and 4 (Yakima Valley) 
deliberately selected for the earlier interviews. Irrigators in the other four G-Strata were targeted for the later interviews because of the later starting dates of their spring work schedules.

Interviews were conducted primarily by NEA personnel, with the assistance, in some cases, of local agricultural consulting firm personnel. A total of 241 on-farm interviews were conducted during the survey. Interviewers were provided the telephone survey completed by the in-person respondent, and they transcribed selected responses from the telephone survey to the in-person questionnaire; this allowed the interviewer to conveniently verify telephone responses and to determine the appropriate skip patterns to employ on the in-person survey. The in-person survey instrument contains notations ( $\star$ TQ\#) referencing the question number from the telephone questionnaire. It should be noted that approximately 20 in-person interviews were conducted without the benefit of having the completed telephone questionnaire at the time of the interview; this resulted from the tight time frame and scheduling logistics whereby alternate respondents had to be recruited in the field when primary candidates for interviewing refused or were unavailable at the scheduled time.

For those respondents who had not a]ready signed and returned a waiver form at the time of the in-person interview, a blank waiver form was provided to the interviewers to be signed by the respondent on site.

A sumary of the distribution of completed in-person survey interviews is provided in Table 3.1 .

\subsection{EDITING AND CALLBACKS}

Completed questionnaires were edited by Market Trends personnel for completeness and consistency; NEA personnel made callbacks to respondents as necessary to resolve areas of concern. Because of the length and complexity of the survey instrument, coupled with the time constraints of farmers during the actual interviews, a majority of questionnaires required callbacks on one or more question areas. For future on-site surveys, more stringent requirements for interviewers to edit their surveys for completeness before leaving the premises are recommended. 
TABLE 3.1. Summary of Completed In-Person Survey Interviews

\section{1}

Utility

Benton County PUD

02 Benton REA

03 Big Bend Electric

05 Columbia REA

06 Douglas County PUD

$07 \quad$ Franklin County PUD

09 Intand Power and Light

\begin{tabular}{|c|c|}
\hline G-Strata & U-Strata \\
\hline 2 & 2 \\
\hline 2 & 4 \\
\hline 2 & 6 \\
\hline
\end{tabular}

Al1

2

2

4

4

4

-

2

2

2

2

2

-

2

2

2

2

2

$-$

6

6

-

2

2

2

2

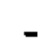

6

3

6

2

3

Al1

2

3

4

5

6

Al1

\section{2}

3

4

5

6

Al1

2
4

A11

2

3

5

6

A) 1

2
Number of Completed Interviews

$\begin{array}{r}9 \\ 1 \\ 13 \\ \hline 23\end{array}$

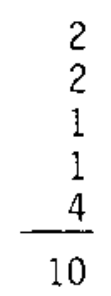

37

$\begin{array}{r}9 \\ 5 \\ 4 \\ 7 \\ 12 \\ \hline 37\end{array}$

2

6

3

4

$-5$

20

1
-3

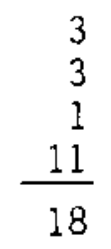

A11 $-\frac{2}{2}$ 
TABLE 3.1. (contd)

\begin{tabular}{|c|c|c|c|c|}
\hline & Utility & G-Strata & U-Strata & $\begin{array}{l}\text { Number of } \\
\text { Completed } \\
\text { Interviews }\end{array}$ \\
\hline \multirow[t]{2}{*}{10} & Kittitas County PUD & $\begin{array}{l}4 \\
4 \\
4 \\
4\end{array}$ & $\begin{array}{l}2 \\
3 \\
4 \\
6\end{array}$ & $\begin{array}{l}1 \\
1 \\
1 \\
1 \\
\end{array}$ \\
\hline & & - & All & 4 \\
\hline \multirow[t]{2}{*}{11} & Klickitat County PUD & $\begin{array}{l}4 \\
4\end{array}$ & $\begin{array}{l}4 \\
6\end{array}$ & $\begin{array}{l}1 \\
1 \\
\end{array}$ \\
\hline & & - & A11 & 2 \\
\hline \multirow[t]{2}{*}{12} & Lincoln Electric Cooperative & $\begin{array}{l}6 \\
6 \\
6\end{array}$ & $\begin{array}{l}2 \\
4 \\
6\end{array}$ & $\begin{array}{r}1 \\
1 \\
3 \\
\end{array}$ \\
\hline & & - & A11 & 10 \\
\hline \multirow[t]{2}{*}{13} & Dkanogan PUD & $\begin{array}{l}4 \\
4 \\
4 \\
4\end{array}$ & $\begin{array}{l}2 \\
3 \\
4 \\
5\end{array}$ & $\begin{array}{l}1 \\
2 \\
1 \\
1 \\
\end{array}$ \\
\hline & & - & Al1 & 5 \\
\hline \multirow[t]{2}{*}{17} & Central Electric Cooperative & $\begin{array}{l}5 \\
5 \\
5\end{array}$ & $\begin{array}{l}2 \\
4 \\
5\end{array}$ & $\begin{array}{l}1 \\
1 \\
2 \\
\underline{2}\end{array}$ \\
\hline & & - & A11 & 4 \\
\hline \multirow[t]{2}{*}{18} & Columbia Basin Electric & 3 & 6 & 4 \\
\hline & & - & A 11 & 4 \\
\hline \multirow[t]{2}{*}{19} & Columbia Power Cooperative & $\begin{array}{l}5 \\
5\end{array}$ & $\begin{array}{l}2 \\
3\end{array}$ & $\begin{array}{l}1 \\
1 \\
\end{array}$ \\
\hline & & - & Al1 & 2 \\
\hline \multirow[t]{2}{*}{22} & Harney Electric & $\begin{array}{l}5 \\
5 \\
5 \\
5\end{array}$ & $\begin{array}{l}2 \\
3 \\
4 \\
6\end{array}$ & $\begin{array}{l}2 \\
1 \\
3 \\
7 \\
\end{array}$ \\
\hline & & - & Tו1 & 13 \\
\hline
\end{tabular}


TABLE 3.1. (contd)

23 Midstate Electric

Utility

26 Surprise Valley Electric

27 Umatilla Electric Cooperative

28 Wasco Electric Cooperative

29 East End Mutual

30 Fall River Cooperative

32 Kootenai Electric Cooperative

34 Raft River Cooperative

36 South Side Electric Lines
Number of

Completed

Interviews

5

5 3

A11

$\begin{array}{r}2 \\ -2 \\ \hline 4\end{array}$

2

A11

$-\frac{2}{2}$

2
3
4
5
6

A11

5

9

4

3

.4

35

3
4
5

All

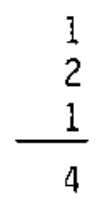

2

Al1

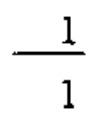

2

A1 1

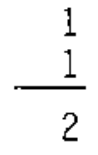

2
3
4

Al1

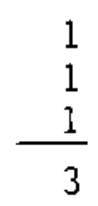

5
6

All

$\begin{array}{r}1 \\ 13 \\ \hline 14\end{array}$

1

2
3
4
6

All

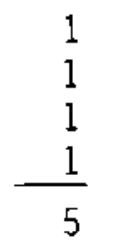


TABLE 3.1. (contd)

39

$\frac{\text { Utility }}{\text { Ravalli County Electric }}$

40

Vigilante Electric Cooperative
TOTAL

A number of editing guidelines and decision rules were utilized in deciding whether a callback was necessary and what data should be entered into the data base. These guidelines and decision rules are listed in Appendix A.

Responses to open-ended and partially open-ended (i.e., "other" responses) questions were coded for computerization. Codes were added for any response category accounting for $5 \%$ or more of responses to that particular question.

\subsection{DATA ENTRY AND PROCESSING}

Data entry of surveys was performed twice to ensure the accuracy of input. Records were matched, with inconsistencies resolved by referring to the original survey instrument.

Data entry and original data processing was conducted on a time-share system, Nordata, in Bellevue, using OPUSl software designed by John Griffin, Bellevue. The data were originally processed on a DEC PDP 11/70 computer. Further processing of the data was performed by PNL using the Statistical Package for the Social Sciences (SPSS ${ }^{x}$ ) software package on PNL's VAX computer. 


\subsection{DATA FORMAT AND CODES}

The original data tape (1600 BPI) developed by Market Trends contains four data bases in ACSII format; the study was divided into four separate data files to avoid exceeding system constraints on record length. The blocking factor is noted on the tape.

\begin{tabular}{|c|c|c|c|c|c|}
\hline \multirow[b]{2}{*}{ File Name } & \multirow[b]{2}{*}{$\begin{array}{c}\text { Number of } \\
\text { Records }\end{array}$} & \multirow[b]{2}{*}{$\begin{array}{c}\text { Corresponding } \\
\text { Questions } \\
\end{array}$} & \multirow{2}{*}{$\begin{array}{c}\text { Number of } \\
\text { Cards per } \\
\text { Record } \\
\end{array}$} & \multicolumn{2}{|c|}{ Columns } \\
\hline & & & & $\begin{array}{l}\text { Record } \\
\text { Number }\end{array}$ & $\begin{array}{l}\text { Card } \\
\text { Number }\end{array}$ \\
\hline 1470.DAT & 241 & $\begin{array}{l}\text { Intro (column } 1-20) \\
0.1-0.53 \\
0.99-0.111 \\
0.113-0.228 \\
0.262-0.327\end{array}$ & 10 & $1(3)$ & $4(2)$ \\
\hline 1470A.DAT & 241 & $\begin{array}{l}\text { Intro (column } 1-20) \\
\quad 2.54-0.98\end{array}$ & 5 & $1(3)$ & 5 \\
\hline 1470B.DAT & 162 & $\begin{array}{l}\text { Intro (column 1-20) } \\
\quad 0.112\end{array}$ & 5 & $1(3)$ & 5 \\
\hline 1470C.DAT & 241 & $\begin{array}{c}\text { Intro (column } 1-20) \\
0.230-0.261\end{array}$ & 3 & $1(3)$ & 5 \\
\hline
\end{tabular}

The three column record number refers to the same record in each of the four data files; that is, record number 001 is the same respondent in each of the four data files. File 1470B.DAT consists of fewer than 241 records as that set of questions (0.112) was asked of those who had taken conservation measures (162 respondents). For convenience, the first card in each record in each of the four data files replicates the classification information from columns 1-20, including ID Number, Questionnaire Number, G Stratum, U Stratum, and Utility.

An SPSS ${ }^{x}$ program was written by PNL personnel to create SPSS ${ }^{x}$ files for use in performing analyses. This program was supplied to Bonneville in association with delivery of the raw data type. The files created by this program have the same names as the four files listed above. 


\subsubsection{Data Format Convention}

The questionnaire provided in Appendix $B$ is the most efficient means of determining the data format. It should be noted that three versions of the questionnaire were used depending on the respondent's utility:

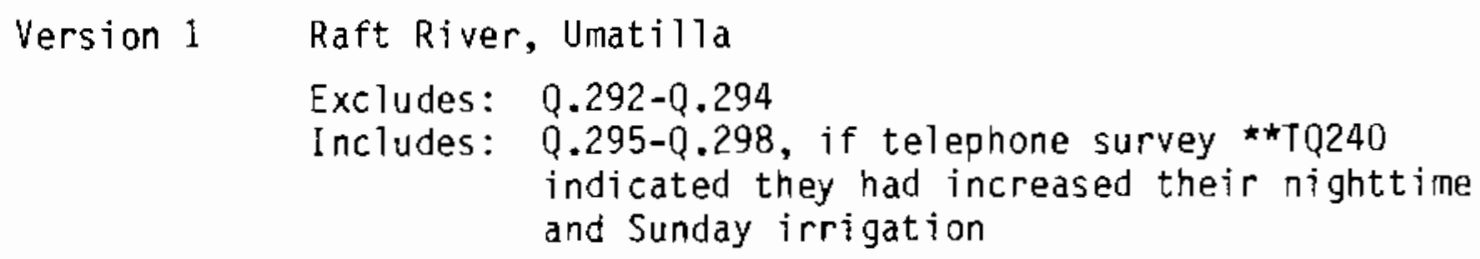

Version 2 Benton County PUD

Excludes: Q.295-Q.298

IncTudes: $0.292-0.294$

Version 3 All Others

Exciudes: $Q .292-Q .298$

Despite the three versions of the questionnaire, the data format of the original data tape across all records is identical. If a question was asked of customers of utility "A" and not of utility "B," the corresponding columns in the record for the utility " 8 " customer are simply left blank.

Blank spaces indicate questions that were inappropriate to ask the respondent (e.g., fell within a skip pattern), unused columns at the end of a card, or columns in a question allowing for multiple maximum allowed. In many instances, questions are asked, or are skipped, based on their responses to certain questions on the telephone survey.

Throughout the questionnaire presented in Appendix B, for each question and/or possible response, the starting column number on the original data tape and field length is noted. Several examples follow: 


\begin{tabular}{|c|c|c|}
\hline \multicolumn{2}{|c|}{$\begin{array}{l}\text { Card/Column } \\
\text { Indicator }\end{array}$} & \multirow[b]{2}{*}{$\begin{array}{l}\text { Notation on } \\
\text { Questionnaire } \\
\end{array}$} \\
\hline $\begin{array}{c}\text { Card } \\
\text { Number }\end{array}$ & $\begin{array}{l}\text { Column } \\
\text { Number }\end{array}$ & \\
\hline 1 & 48 & $48^{(a)}$ \\
\hline 2 & 48 & 2.48 \\
\hline 12 & 48 & 12.48 \\
\hline
\end{tabular}

(a) Card number 1 implied.

Field widths are expressed by a number in parenthes is after the card number. A field width of one column is generally implied, and there is no number in parenthesis.

\begin{tabular}{|c|c|}
\hline $\begin{array}{l}\text { Field width } \\
\text { (Number of } \\
\text { Columns) }\end{array}$ & $\begin{array}{l}\text { Notation on } \\
\text { Questionnaire }\end{array}$ \\
\hline 1 & 2.48 \\
\hline 2 & $2.48(2)$ \\
\hline 3 & $2.48(3)$ \\
\hline 4 & $2.48(4)$ \\
\hline 5 & $2.48(5)$ \\
\hline
\end{tabular}

In the case of multiple column fields, the subsequent column indicator notation on the questionnaire will. pick up at the starting point of the field (e.g., 2.48(5), 2.53).

The allowance for multiple mentions is signified by a start ("«") after the column/field width notation. Data are filled in the data base based on the number of mentions provided by the respondent; if they do not use all the mentions allowed, the remaining columns in the field will be blank. 
Examples

\begin{tabular}{|c|c|c|}
\hline $\begin{array}{l}\text { Number of } \\
\text { Mentions } \\
\text { Allowed }\end{array}$ & $\begin{array}{c}\text { Notation on } \\
\text { Questionnaire }\end{array}$ & $\begin{array}{l}\text { Starting } \\
\text { Point of } \\
\text { Subsequent } \\
\text { Field }\end{array}$ \\
\hline $\begin{array}{l}1 \\
3 \\
5\end{array}$ & $\begin{array}{l}2.48 \\
2.48 \star 3 \\
2.48 \star 5\end{array}$ & $\begin{array}{l}2.49 \\
2.51 \\
2.53\end{array}$ \\
\hline $\begin{array}{l}1 \\
3 \\
5\end{array}$ & $\begin{array}{l}2.48(2) \\
2.48(2) * 3 \\
2.48(2) * 5\end{array}$ & $\begin{array}{l}2.50 \\
2.54 \\
2.58\end{array}$ \\
\hline $\begin{array}{l}1 \\
3 \\
5\end{array}$ & $\begin{array}{l}2.48(3) \\
2.48(3) \star 3 \\
2.48(3) \star 5\end{array}$ & $\begin{array}{l}2.51 \\
2.57 \\
2.63\end{array}$ \\
\hline
\end{tabular}

In several instances on the questionnaire, a matrix is to be filled in, as appropriate. To facilitate data entry, the format notations have been abbreviated.

\begin{tabular}{|c|c|c|}
\hline$\frac{\text { Example }}{0.263,0.271,0.279}$ & $\begin{array}{l}\text { Notation on } \\
\text { Questionnaire }\end{array}$ & $\begin{array}{l}\text { Starting } \\
\text { Point of } \\
\text { Subsequent } \\
\text { Field }\end{array}$ \\
\hline $\begin{array}{l}\text { Hours per day irrigate in } \\
\text { April--2 columns }\end{array}$ & $9.7(2)(3)(1)$ & 9.13 \\
\hline $\begin{array}{l}\text { Percent system capacity } \\
\text { used in April--3 columns }\end{array}$ & & \\
\hline $\begin{array}{l}\text { Potential to increase irri- } \\
\text { gation in April--1 column }\end{array}$ & & \\
\hline
\end{tabular}

The variable names produced by the program that creates the SPSS ${ }^{x}$ file and their location within the file are also shown in Appendix B. Each variable is identified and its location in the SPSS ${ }^{x}$ file is noted in parentheses. For example, the response to the first question on the survey is labeled Q1 (1/21) and represents the SPSS ${ }^{x}$ variable Q1 located in the first card of the SPSS file, with a starting and ending location of column 21. As noted previously, the Four SPSS files created by the program have the same names and contain the same question responses as the files listed in Section 3.6 . 


\subsubsection{Data Codes}

The following data code conventions have been followed for certain types of responses, per the request of BPA. They are also noted on the questionnaire itself.

\section{Examples}

\begin{tabular}{|c|c|c|c|c|}
\hline \multirow[b]{2}{*}{ Designation/"Punch" } & \multicolumn{4}{|c|}{ Field Width } \\
\hline & I Column & 2 Columns & 3 Columns & 5 Columns \\
\hline Not Asked/Inappropriate to Ask & 6 & 96 & 996 & 99996 \\
\hline Not applicable & 7 & 97 & 997 & 99997 \\
\hline Don't know & 8 & 98 & 998 & 99998 \\
\hline Refused & 9 & 99 & 999 & 99999 \\
\hline
\end{tabular}

In the data base, "not applicable" responses resulting from a skip pattern (inappropriate to ask question of respondent) are blank to avoid confusion with "true" not applicable responses.

In the case of yes/no questions (also noted on the questionnaire), the following convention was followed:

$$
\begin{aligned}
\text { Yes } & =1 \\
\text { No } & =0 \\
\text { Don't know } & =8
\end{aligned}
$$

In certain open-ended questions, response codes were added after the questionnaire was finalized. The decision rule to add a particular code was that $5 \%$ of those responding to the question must give a similar response. Thus, if 1,000 people were asked a particular question, 50 or more similar responses would be needed to warrant an added code. If 100 people were asked the question (e.g., question fell within a skip pattern so not all respondents were asked), five or more similar responses would warrant a code. A11 codes added to the survey are summarized in Table 3.2. 
TABLE 3.2. Added Data Codes--Decjsion Rule: At Least 5\% of Responses to the Particular Question (a) Fall into the Particular Category

\begin{tabular}{|c|c|c|c|}
\hline $\begin{array}{l}\operatorname{SPSS}^{\mathrm{x}} \text { Variable } \\
\text { (Location) } \\
\end{array}$ & $\begin{array}{c}\text { Question Number/ } \\
\text { Column Number }\end{array}$ & Code & Interpretation \\
\hline $\begin{array}{l}Q .128 C \\
(6 / 55)\end{array}$ & $\begin{array}{l}0.137 \\
6.55\end{array}$ & $\begin{array}{l}1 \\
2 \\
6\end{array}$ & $\begin{array}{l}\text { Other } \\
\text { Experience } \\
\text { Unsure/Don't know }\end{array}$ \\
\hline $\begin{array}{l}Q .129 C \\
(6 / 58)\end{array}$ & $\begin{array}{l}0.138 \\
6.58\end{array}$ & $\begin{array}{l}1 \\
2 \\
6\end{array}$ & $\begin{array}{l}\text { Other } \\
\text { Experience } \\
\text { Unsure/Don't know }\end{array}$ \\
\hline $\begin{array}{l}Q .130 C \\
(6 / 59)\end{array}$ & $\begin{array}{l}0.139 \\
6.61\end{array}$ & $\begin{array}{l}1 \\
2 \\
6\end{array}$ & $\begin{array}{l}\text { Other } \\
\text { Experience } \\
\text { Unsure/Don't know }\end{array}$ \\
\hline $\begin{array}{l}0.131 C \\
(6 / 64)\end{array}$ & $\begin{array}{l}0.140 \\
6.64\end{array}$ & $\begin{array}{l}1 \\
2 \\
6\end{array}$ & $\begin{array}{l}\text { Other } \\
\text { Experience } \\
\text { Unsure/Don't know }\end{array}$ \\
\hline $\begin{array}{l}0.132 C \\
(6 / 67)\end{array}$ & $\begin{array}{l}0.141 \\
6.67\end{array}$ & $\begin{array}{l}1 \\
2 \\
6\end{array}$ & $\begin{array}{l}\text { Other } \\
\text { Experience } \\
\text { Unsure/Don't know }\end{array}$ \\
\hline $\begin{array}{l}0.133 C \\
(6 / 70)\end{array}$ & $\begin{array}{l}0.142 \\
6.70\end{array}$ & $\begin{array}{l}1 \\
2 \\
6\end{array}$ & $\begin{array}{l}\text { Other } \\
\text { Experience } \\
\text { Unsure/Don't know }\end{array}$ \\
\hline $\begin{array}{l}Q .134 C \\
(6 / 73)\end{array}$ & $\begin{array}{l}Q .143 \\
6.73\end{array}$ & $\begin{array}{l}1 \\
2 \\
6\end{array}$ & $\begin{array}{l}\text { Other } \\
\text { Experience } \\
\text { Unsure/Don't know }\end{array}$ \\
\hline $\begin{array}{l}Q .135 C \\
(6 / 76)\end{array}$ & $\begin{array}{l}0.144 \\
6.76\end{array}$ & $\begin{array}{l}1 \\
2 \\
6\end{array}$ & $\begin{array}{l}\text { Other } \\
\text { Experience } \\
\text { Unsure/Don't Know }\end{array}$ \\
\hline $\begin{array}{l}Q .136 C \\
(6 / 79)\end{array}$ & $\begin{array}{l}0.145 \\
6.79\end{array}$ & $\begin{array}{l}1 \\
2 \\
6\end{array}$ & $\begin{array}{l}\text { Other } \\
\text { Experience } \\
\text { Unsure/Don't know }\end{array}$ \\
\hline $\begin{array}{l}Q .224 \mathrm{~A}, \mathrm{Q} .224 \mathrm{~B} \\
(8 / 65)(8 / 66)\end{array}$ & $\begin{array}{l}Q .224 \\
8.65 * 2\end{array}$ & 3 & Doesn't Apply or Meet Needs \\
\hline
\end{tabular}

(a) Examples: If 1,000 people were asked the question, at least 50 similar responses are required to warrant a new code. If 100 people were asked the question, the rule would be at least 5 similar responses. 
Codes were added for the "Five Years From Now" columin in situations in which respondents anticipated an increase or decrease but could not provide an accurate estimate of actual acreage in Q.248B to Q.261:

99994 - Increase in acreage, but unsure of amount

99995 - Decrease in acreage, but unsure of amount

\subsection{DATA INTERPRETATION}

In light of the methodology of in-person interviewing, where the interviewer can observe the farmer's situation first hand, and can elaborate on the intent of particular question areas, some general coments about the gathering process are useful. These comments, supplied by Dave Ricks of NEA (who personally conducted a number of in-person interviews) are as follows:

- Billing account names are a matter of recollection to some respondents; this is more the case in family farms comprised of brothers or of fathers and sons. Some respondents are not positive as to whose name is actually on the bill.

- Q.53 - Mixed hay and alfalfa crops are reported in the hay category.

- Q.100-Q.108 - Water applications have an "80\% likelihood of being a guess" according to Mr. Ricks.

- Q.111 - Pumping plant efficiency results are questionable. For example, if a pump is rated at 500 gallons per minute and puts out 500 gallons per minute, the farmer may view this as $100 \%$ efficiency.

- Q.112 - "Changes" may have been built into the design of the system when installed, rather than being a change made to an existing systeri. In-person results are viewed as more accurate than telephone survey results.

- Q.171-Q.211 - To determine the appropriate skip patterns, inter viewers had to rely on both the telephone survey results and their knowledge of the farmers' situation based on the in-person visit. In some cases, simply following the skip patterns based on telephone results would be inappropriate given new information; for example, at 
least one farmer felt he had a low pressure system because he was pumping uphill. The skip patterns followed by in-person interviewers are therefore seen as more appropriate than would be the case if strictly following telephone results.

- Q.248B-Q.261 - "Past Season" figures were based on responses to inperson questions, and not telephone responses as indicated on the column heading; this was viewed as a more accurate approach. Any discrepancies between this series of questions, Q.1, and Q.54-Q.98, according to Mr. Ricks, would likely be attributed to idle land/set-aside.

These comments serve to illustrate the weaknesses of using telephone survey responses as a basis for certain types of quantitative data. Because of these weaknesses, it is believed that BPA's irrigation system audits provide a better source of data for such parameters as pumping plant efficiencies than do the survey results. The survey results will remain the primary data source for parameters for which a more accurate source is unavailable, such as irrigated acres by type of system used. 



\subsection{SPECIFIC QUESTIONS AND ANSWERS FROM SURVEY RESULTS}

\subsection{QUESTION 1}

How can the irrigation customer market be segmented in terms of adopters and non-adopters of energy-saving technologies and what are the relative importance of factors that may have influenced adoption versus non-adoption?

\subsubsection{Approach to Question 1}

Segmenting the irrigation customer market in terms of adopters and nonadopters of energy-saving technologies is a technique for determining the unique characteristics of the two groups. The results of this analysis can fllustrate the factors that determine adoption and non-adoption of energysaving technologies and be used in evaluating current conservation programs and planning for future programs.

In order to address the segmentation of the irrigation customer market, attention was focused on explaining the adoption and non-adoption of lowpressure irrigation on center-pivot systems. This conservation technology has been rapidly adopted by irrigators. Over 50 percent of irrigators responding to the telephone survey reported adopting this technology. A breakdown of telephone survey respondents by their reported first year of installation of low-pressure irrigation on center-pivots is shown in Table 4.1. Note from this table that reported adoption was relatively infrequent in the first two years of the specified time period. After the first two years, adoption increased significantly and remained relatively stable through 1985 (the most recent year for which data is available from the survey).

The segmentation of adopters and non-adopters of low-pressure irrigation on center-pivot systems was examined using a technique known as discriminant analysis. In essence, discriminant analysis "discriminates" between groups of interest (in this case, adopters versus non-adopters of low-pressure irrigation on center-pivot systems) by maximizing the ration of "between-group variation" to "within-group variation." 
TABLE 4.1. Number of Irrigators Reporting First-Year Adoption of LowPressure Irrigation on Center-Pivot Systems

\begin{tabular}{lcc}
$\begin{array}{l}\text { First Year } \\
\text { of Adoption }\end{array}$ & $\begin{array}{c}\text { Number of } \\
\text { Irrigators }\end{array}$ & $\begin{array}{c}\text { Percent of Total } \\
\text { Comprised by Year }\end{array}$ \\
\cline { 2 - 3 } 1978 & 12 & 4.0 \\
1979 & 15 & 5.6 \\
1980 & 46 & 17.6 \\
1981 & 38 & 14.3 \\
1982 & 45 & 16.9 \\
1983 & 44 & 16.5 \\
1984 & 29 & 10.9 \\
1985 & 37 & 13.9
\end{tabular}

The basic approach of discriminant analysis is similar to that employed in regression analysis. In both cases, weighted linear combinations of independent variables are used to predict a dependent variable. In discriminant anaiysis, the dependent variable is group membership. The general form of the discriminant function is:

$$
y=v_{1} x_{1}+v_{2} x_{2}+\ldots \cdot v_{n} x_{n}
$$

where $\quad Y=$ The dependent variable for adoption or non-adoption of lowpressure irrigation on center-pivot systems.

$x_{1}, x_{2} \ldots x_{n}=$ The independent variables influencing adoption or nonadoption of low-pressure irrigation on center-pivot systems.

$v_{1}, v_{2} \ldots v_{n}=$ The calculated weights for the independent variables influencing adoption.

The results of discriminant analysis cam be used for predicting future adoption of products or technologies and identifying target markets. For example, if it were determined through discriminant analysis that a specific 
type of industrial plant were more likely to have adopted an electrotechnology, then future marketing efforts for electro-technologies could be channeled towards this type of plant.

Discrimination analysis results can also be used for evaluating the impacts of various factors on group membership for purposes of program evaluation. In terms of Bonneville's current needs, this is likely to be the more important application of the discriminant technique. For example, the impacts of various types of informational sources on conservation technoiogy adoption can be tested using discriminant analysis.

Of the 503 respondents to the telephone survey that reported having a center-pivot system, 272 also reported that they had installed low-pressure irrigation. The objective of the discriminant analysis performed in this study was to explain the major factors that distinguished those reporting adoption of low-pressure on center-pivot systems from those not reporting adoption of lowpressure.

The factors used in explaining adoption versus non-adoption of lowpressure were selected on the basis of four primary criteria: 1) availability of data from the survey, 2) economic theory, 3) marketing theory, and 4) knowledge of the characteristics of the irrigation sector. The factors selected for use in explaining adoption versus non-adoption of low-pressure on center-pivots are summarized in Table 4.2. Brief summaries of each of the selected factors are presented below.

A number of farm characteristic variables were thought to be potentially related to the probability of the adoption of 1 ow-pressure irrigation. It is generally believed that larger farmers are more likely to have adopted lowpressure irrigation than smaller farmers, primarity because of the higher level of financial resources that are perceived to be available to larger farmers.

Pumping lift is believed to potentially effect the likelihood of lowpressure adoption because of its impact on irrigation costs. Other factors held constant, the higher the pumping lift of an irrigation system, the higher 
TABLE 4.2. Factors Selected for Use as Independent Variables in a Discriminant Analys is Explaining Adoption Versus NonAdoption of Low-Pressure Irrigation

\begin{tabular}{|c|c|c|}
\hline $\begin{array}{l}\text { Farm Characteristic } \\
\text { Variables }\end{array}$ & $\begin{array}{c}\text { Respondent Characteristic } \\
\text { Variables }\end{array}$ & Informational Variables \\
\hline Farm size & Education level & $\begin{array}{l}\text { Frequency of attendance at } \\
\text { local agricultural shows }\end{array}$ \\
\hline Pumping 1 ift & $\begin{array}{l}\text { Respondent type (owner- } \\
\text { operator farm manager) }\end{array}$ & $\begin{array}{l}\text { Frequency of magazine } \\
\text { use }\end{array}$ \\
\hline $\begin{array}{l}\text { Utility type (private } \\
\text { versus public) }\end{array}$ & Age & $\begin{array}{l}\text { Frequency of interaction with } \\
\text { the electric utility or its } \\
\text { its contractors }\end{array}$ \\
\hline \multirow[t]{6}{*}{ Geographic area } & Future out look & $\begin{array}{l}\text { Frequency of interaction } \\
\text { with Bonneville }\end{array}$ \\
\hline & & $\begin{array}{l}\text { Frequency of interaction with } \\
\text { equipment salesman }\end{array}$ \\
\hline & & $\begin{array}{l}\text { Frequency of interaction with } \\
\text { neighbors and friends }\end{array}$ \\
\hline & & $\begin{array}{l}\text { Frequency of interaction with } \\
\text { the county extension service }\end{array}$ \\
\hline & & $\begin{array}{l}\text { Frequency of interaction with } \\
\text { the Soil Conservation Service }\end{array}$ \\
\hline & & $\begin{array}{l}\text { Frequency of interaction with } \\
\text { the irrigation district }\end{array}$ \\
\hline
\end{tabular}

the irrigation costs. Farms with higher irrigation costs should be more likely to adopt low-pressure because of the the greater cost savings available from such adoption.

Utility type is a variable distinguishing farms served by private utilities from those served by public utilities. Because private utilities generally have higher rates, it was thought that their customers may be more likely to have adopted low-pressure. Geographic area is a variable included in the analysis to determine if location had an effect on low-pressure adoption. It 
was postulated that low-pressure adoption in high evaporation, low-rainfall areas was likely to be more frequent because of the relatively higher irrigation costs in these areas.

\section{Respondent Characteristics Variables}

Respondent characteristic variables represent specific characteristics of the survey respondents that were postulated to affect the adoption of lowpressure irrigation. Although few of these variables were available in the survey results, one potentially important variable that was available was years of education. It was thought that increased education of a respondent may increase the likelihood of low-pressure adoption. The variable "respondent type" distinguishes owner-operators of farms from farm managers for corporation. It was thought that farm managers for corporations may have been more likely to have adopted low-pressure irrigation because of their greater access to financial resources.

Age of the respondent was selected as an explanatory variable based on the hypothesis that younger farmers may have been more receptive to the adoption of new technology than older farmers. Future outlook is a variable reflecting respondents views about the relative profitability of farming over the next three years. It was believed that farmers that were more optimistic about future profitability may have been more likely to have installed low-pressure than less optimistic farmers.

Informationa? Variables

Frequency in the use of informational sources was thought to have a potentially significant impact on the adoption of low-pressure irrigation. These variables are important from a policy standpoint because they can serve as potential examples of the impacts of informational programs (such as Bonneville's irrigation system audit program) on the adoption of conservation technologies. All of the informational variables listed in Table 4.2 were thought to have a positive impact on the adoption of low-pressure irrigation. That is, the more frequently the information sources on conservation technologies were reported to be used, the greater the likelihood of low-pressure adoption. 
The specific questions from the telephone survey used in the discriminant analysis are as follows:

TQ.1

How many acres of cropland are on this farm?

$T Q .3$

TQ.6

Of the totai (acreage on your farm) how many are set up for irrigation?

Of your acres set up for irrigation about how many are or would be irrigated with surface water from ponds, rivers, or canals?

$\mathrm{TQ} .7$

What is the average total pump lift from these surface water sources?

TQ.8 Of your acres set up for irrigation about how many are or would be irrigated with groundwater from wells?

TQ.9 What is the average pump lift from these wells?

TQ.18 Please tell me which of the following irrigation systems you use on your farm?

- Center-pivot

- Wheel line

- Hand set

- Solid set

- Ri11

- Flood

$T Q .80$

Which, if any, of the following changes have been made in your farm irrigation systern since 1978 ?

- Added low head sprinklers on center-pivot systems

TQ.165-TQ.174 I am going to read several sources of information and assistance on energy-efficient irrigation practices. For each please tell me whether you use it often, sometimes or never.

- Local agricultural shows, such as country fairs

- Trade or farm magazines

- Your local electric utility or its contractors 
- The Bonneville Power Administration

- Equipment salesman

- Neighbors and friends

- Your county agricultural extension service

- The state energy extension service

- Your irrigation district

TQ.208

Over the next three years, do you think farming in general throughout the Pacific Northwest will be:

- More profitable than the last 3-year average,

- Less profitable than the last 3-year average, or

- About the same as the past 3-year average

TQ.254

May I ask your age?

$\mathrm{TQ} .256$

What was the last grade of education you had the opportunity to complete?

$\mathrm{TQ} .257$

What is your position on the farm?

- Owner/Operator

- Manager for Corporation

- Partner

- Agricultural Engineer

- Irrigation System Manager

- Other . .

\section{1 .2 Results}

Results pertaining to the overall success of the specified discriminant function in segmenting center-pivot owners into adopters and non-adopters of low-pressure irrigation are illustrated by data presented in Table 4.3. The generalized squared distance is a measure of the success of the discriminant function in minimizing the variation within groups while maximizing the variation between groups. It measures the distance from each adopter to the predicted group mean. Note that the generalized squared distance of actual adopters from the adopter group mean (14.6) is less than the distance of actual non-adopters from the adopter group mean (15.1). Similarly, the generalized squared distance of actual non-adopters from the non-adopter group mean (12.9) 
TABLE 4.3. Overall Discriminant Function Results for Low-Pressure Adopters Versus Non-Adopters

Actual Generalized Squared Distance Classification Adopters Non-Adopters

$\frac{\text { Adopters }}{14.6}$

15.1
Percentages Classified Adopters Non-Adopters

$$
72.2 \quad 27.8
$$

19.4

80.6

$$
\begin{aligned}
& \text { Overall Chi-Square for Function }=415.8 \\
& \text { Probability Level for Chi-Square }=.0005
\end{aligned}
$$

is less than the distance of actual adopters from the non-adopter group mean (13.5). Thus, the discriminant function was successful in reducing withingroup variation while increasing between-group variation.

The "percentage classified" data shown in Table 4.3 indicate the "hit rate" for the discriminant function in terms of its ability to correctly classify respondents. For example, this data indicated that the specified discriminant function was able to correctly classify $72.2 \%$ of actual lowpressure adopters as low-pressure adopters and that the function misclassified $27.8 \%$ of actual low-pressure adopters as non-adopters. Similarly, $80.6 \%$ of actual non-adopters were classified as non-adopters, while $19.4 \%$ of actual nonadopters were misclassified as adopters. The average "hit rate" for the function in terms of correct predictions was $76.4 \%$. Because any "hit rate" in excess of $62.5 \%$ should be regarded as evidence of a good predictive model for the sample used in this analysis (Hair, et a1. 1979), the specified discriminant function appears to have substantial predictive power. The statistical validity of the function is further evidenced by the large chiSquare value that indicates the results have only a .0005 probability of being caused by chance (i.e., the results are statistically significant at more than a $99 \%$ level of confidence).

Results pertaining to the impacts of the individual variables selected to segment adopters of low-pressure from non-adopters are shown in Table 4.4 . Many of the variables selected for the discriminant function were found to be statistically non-significant. Of those found to be significant, the following results are noted: 
TABLE 4.4. Summary of Resuits for Variables Incorporated in the Discriminant Function

\begin{tabular}{|c|c|c|c|}
\hline Variable & F value & $\begin{array}{c}\text { Significant } \\
\text { At } 10 \text { Percent Level }\end{array}$ & $\begin{array}{l}\text { Effect on Adoption } \\
\text { of Low-Pressure }\end{array}$ \\
\hline Acres Irrigated & 7.58 & Yes & + \\
\hline Acres in Cropland & 4.53 & Yes & + \\
\hline Pumping Lift & 2.23 & No & + \\
\hline Utility Type & .63 & No & - \\
\hline G-Stratum 1 & .07 & No & - \\
\hline G-Stratum 2 & .82 & No & - \\
\hline G-Stratum 3 & 5.90 & Yes & + \\
\hline G-STRATUM 4 & 1.30 & NO & - \\
\hline G-STRATUM 5 & .38 & NO & - \\
\hline G-STRATUM 6 & .06 & NO & + \\
\hline G-STRATUM 7 & .28 & NO & - \\
\hline Respondent Education & .97 & No & - \\
\hline Respondent Type & .01 & No & + \\
\hline Respondent Age & .07 & No & - \\
\hline Respondent Outlook & 2.67 & Yes & + \\
\hline Trade Show Frequency & .38 & No & + \\
\hline Magazine Frequency & 2.06 & No & + \\
\hline Utility Frequency & 2.75 & Yes & + \\
\hline BPA Frequency & 3.24 & Yes & + \\
\hline Salesmen Frequency & 1.33 & No & + \\
\hline Neighbors F requency & 3.47 & Yes & + \\
\hline County Ext. Frequency & 2.18 & No & + \\
\hline Energy Ext. Frequency & 2.89 & Yes & + \\
\hline SCS F requency & .96 & No & - \\
\hline Irr. District Frequency & .07 & No & + \\
\hline
\end{tabular}

- Increasing farm size appeared to have a strong positive effect on the adoption of low-pressure on center-pivot.

- Location in G-Stratum 3 (North-Central Oregon) increased adoption of low-pressure on center-pivot. 
- A more positive outlook on the future profitability of farming increased adoption of low-pressure on center-pivot.

- Most of the informational frequency variables, including frequency in the use of utilities, Bonneville, neighbors, and the Energy Extension Service as information sources, increased adoption of low-pressure on center-pivot.

As is often the case in a specification like the one used in this study, multi-collinearity was believed to be a potential statistical problem. To address this problem, a step-wise regression procedure was performed on the data. In general, the final results of the step-wise regression procedure were consistent with those shown in Table 4.4. The exceptions were in the informational frequency variables where all of these variables except SCS Frequency were found to be statistically non-significant at the $10 \%$ level. The impact of the SCS Frequency variable remained negative in the step-wise regression, indicating that increasing frequency of contact with the SCS decreased the adoption of low-pressure on center-pivot. This result is interesting because of the concern that was frequently expressed regarding the potential for lowpressure irrigation to increase soil erosion.

To resolve inconsistencies in the statistical results for the informational variables, a factor analysis was performed in an attempt to narrow the definition of the variables. This analysis indicated that based on factor loadings, the informational variables could logically be redefined into the three new variables shown in Table 4.5 .

The results of the overali discriminant analysis using the redefined variables are shown in Table 4.6. The function was again successful in reducing the "within-group covariance" while increasing the "between-group covariance." The average "hit-rate" for the function fell to $68.9 \%$, but again this level well exceeded the $62.5 \%$ leve 1 that should be regarded as indicating a good predictive model. The specified function is able to classify $72.5 \%$ of low-pressure adopters and $65.3 \%$ of non-adopters into their correct classification. 
TABLE 4.5. Informational Variable Definitions Derived from Factor Analys is Loadings

$\frac{\begin{array}{l}\text { New Variable } \\ \text { Name }\end{array}}{\text { INF01 }}$

INF02

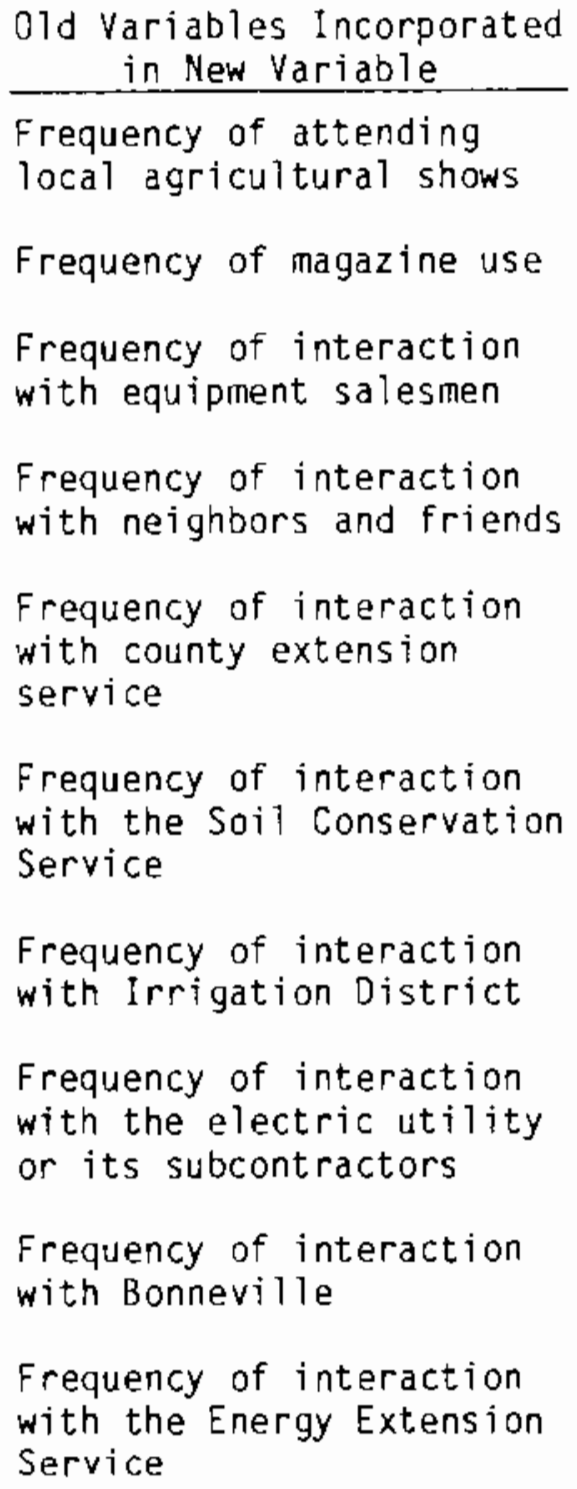

The results for the individual variables used in the discriminant function are shown in Table 4.7. These results are generally consistent with those presented in Table 4.4. Many of the variables were again statistically nonsignificant at the $10 \%$ level. Major findings related to variables that were found to be significant include:

- Increasing farm size had a strong, positive effect on adoption of low-pressure on center-pivot systems. 
TABLE 4.6. Overall Discriminant Function Results for Low-Pressure Adopters Versus Non-Adopters Using Redefined Informational Variables

Actual Classification Adopters

Non-Adopters
Generalized Squared Distance Adopters Mean Non-Adopters Mean 5.65 5.17

Percentages Classified Adopters Non-Adopters

$$
\begin{aligned}
\text { Overall Chi-Square for Function } & =205.6 \\
\text { Probability Level for Chi-Square } & =.0001
\end{aligned}
$$

TABLE 4.7. Summary of Results for Redefined Variables Incorporated in the Discriminant Function

\begin{tabular}{|c|c|c|c|}
\hline Variable & F Value & 10 Percent LeveI & of Low-Pressure \\
\hline Acres Irrigated & 7.58 & Yes & + \\
\hline Pumping Lift & 2.23 & No & + \\
\hline Utility Type & .63 & No & - \\
\hline G-Stratum 1 & .07 & No & - \\
\hline G-Stratum 2 & .82 & No & - \\
\hline G-Stratum 3 & 5.89 & Yes & + \\
\hline G-Stratum 4 & 1.30 & No & - \\
\hline G-Stratum 5 & .38 & No & - \\
\hline G-Stratum 6 & .06 & No & + \\
\hline G-Stratum 7 & .28 & No & - \\
\hline Respondent Education & .91 & No & - \\
\hline Respondent Type & .01 & No & + \\
\hline Respondent Age & .07 & No & - \\
\hline Respondent Outlook & 2.67 & Yes & + \\
\hline INF01 & 3.17 & Yes & + \\
\hline INF02 & .12 & No & + \\
\hline INF03 & 5.55 & Yes & + \\
\hline
\end{tabular}

Significant at Effect on Adoption 
- Location in G-Stratum 3 (North-Central Oregon) had a strong, positive effect on adoption of low-pressure on center-pivot systems.

- Increasing optimism about the future profitability of farming had a positive effect on low-pressure adoption.

- Increasing frequency of contact with general sources of information, such as trade shows and farm magazines, had a positive effect on lowpressure adoption.

- Increasing frequency of contact with energy-related organizations, such as utilities, Bonneville and the Energy Extension Service, had a strong, positive effect on low-pressure adoption.

A step-wise regression procedure was again implemented on the discriminant function described in Table 4.6. The results of this procedure were consistent with those shown in Table 4.7, indicating that grouping the informational variables had successfully reduced the multi-collinearity problems present in the original specification.

The results of the discriminant analysis performed in this study have several important implications for Bonneville programs in the irrigation sector. The positive relationship between farm size and adoption of low-pressure indicates that larger farmers are much more likely to be early adopters of conservation technologies. Thus, Bonneville programs targeted towards small and medium-sized farmers can have a positive influence on adoption of conservation technologies by these farmers.

The positive relationship between the informational variables (particularly those associated with energy-related sources) and adoption of lowpressure indicate that programs like Bonneville's irrigation system audit program can have a positive influence in encouraging technology adoption. The effects of informational programs are often subtle, and go well beyond the direct impacts indicated by participation in Bonneville's Stage II retrofit program. The results of the analysis performed in this study have quantitatively demonstrated the positive impacts of informational programs on technology adoption and indicate that properly designed programs can be useful vehicles for encouraging the efficient use of electrical energy. 


\subsection{QUESTION 2}

How did those irrigators who have taken conservation actions in the last seven years first become aware of the possibility of undertaking such actions, what conditions were necessary to convince them to take such actions, and what. were their initial concerns about undertaking conservation actions?

\subsubsection{Approach to Question?}

In order to answer Question 2, the following questions from the in-person survey were used:

IPQ.171 Regarding low-pressure on center-pivot, where did you first learn of the possibility of installing low-pressure equipment to reduce energy use?

IPQ.172 what kind of information was necessary to convince you that installing low-pressure center-pivot equipment would be a good investment on your farm?

IPQ.173 When you invested in low-pressure equipment, what, if anything, were your major concerns about such equipment?

IPQ.184 Regarding low-pressure equipment on handset/wheel lines, where did you first learn of the possibility of installing low-pressure equipment on these irrigation systems to reduce energy use?

IPQ.185 What kind of information was necessary to convince you that installing low-pressure equipment would be a good investment on your farm?

IPQ.186 When you invested in low-pressure equipment, what, if anything, were your major concerns about such equipment?

IPQ.203 Regarding larger mainlines, where did you first learn of the possibility of installing larger mainlines on your irrigation system to reduce energy use?

IPQ.204 What convinced you that installing larger mainlines would be a good investment on your farm? 
IPQ.215 What information was recessary in order to convince you to use checkbook balancing, computerized scheduling, or other systematic scheduling methods?

IPQ.217 What were your major concerns, if any, when you started using this method?

Information from the responses to these questions were compiled into several tables in order to address Question 2.

\subsubsection{Results}

Results pertaining to Question 2 are shown in Tables 4.8 to 4.10. The interesting feature of Table 4.8 is that irrigation equipment manufacturers and farm magazines appear to be the major initial information sources used by adopters of irrigation system conservation measures. Other sources, such as neighbors and utility representatives, were mentioned much less frequently as initial sources of information. Personal experience was mentioned as a major source of initial information for mainline modification, indicating that increasing mainline size is a relatively well-known method of reducing energy use on irrigation systems.

TABLE 4.8. Percentage of Conservation Measure Adopters Who First Learned of the Possibility of Installing Conservation Measures from Various Information Sources

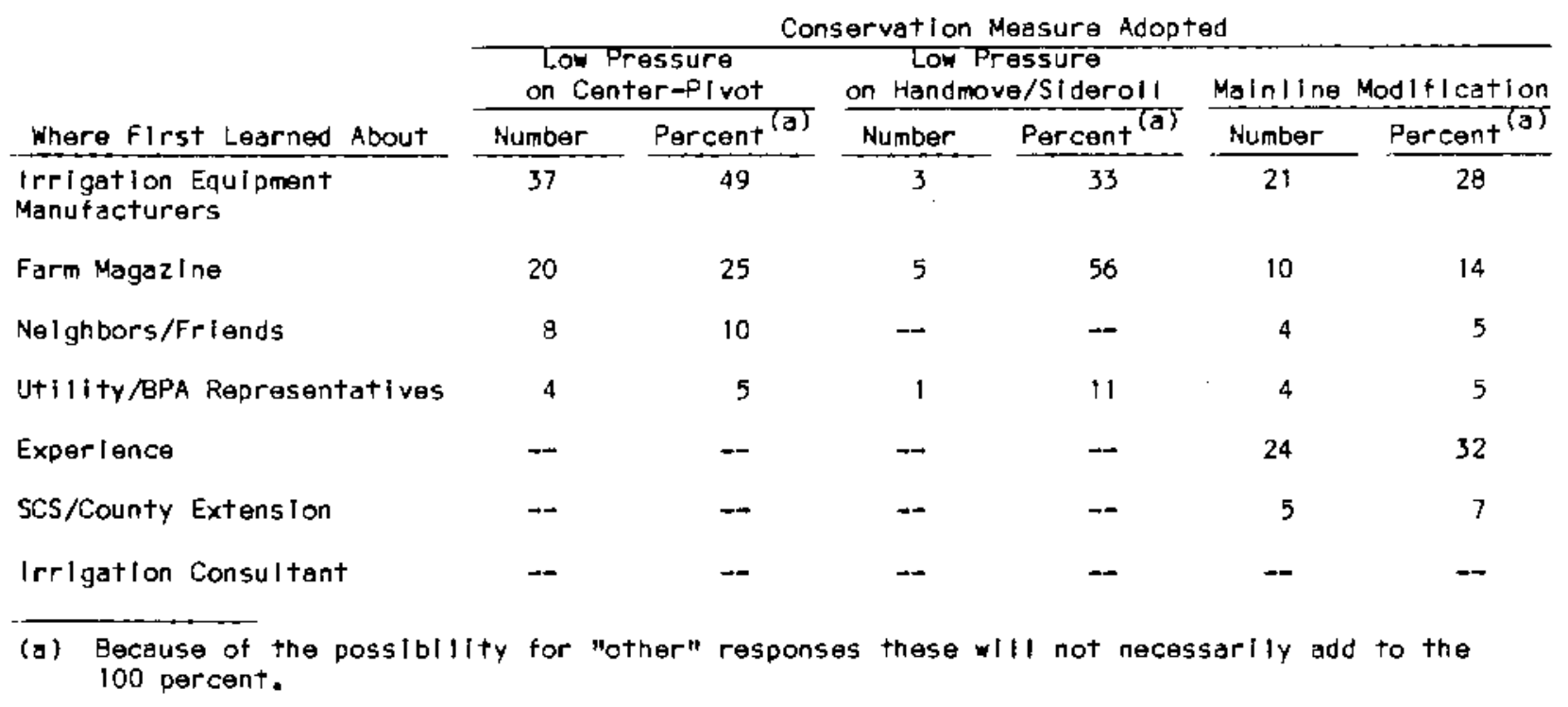


TABLE 4.9. Percentage of Conservation Measure Adopters who Indicated They Were Convinced to Adopt Conservation Measures by Various Means

\begin{tabular}{|c|c|c|c|c|c|c|c|}
\hline \multicolumn{2}{|c|}{$\begin{array}{l}\text { Low Pressure } \\
\text { on Center-Pivot }\end{array}$} & \multicolumn{2}{|c|}{$\begin{array}{l}\text { Low Prassure } \\
\text { on Handmove/Siderall }\end{array}$} & \multicolumn{2}{|c|}{ Mainline Modification } & \multicolumn{2}{|c|}{ Systematic Scheduling } \\
\hline Number & Percent ${ }^{(a)}$ & Number (a) & Percent ${ }^{(a)}$ & Number & - Percent (a) & Number & Percent (a) \\
\hline 10 & 13 & 1 & 11 & 4 & 5 & 4 & 10 \\
\hline 33 & 42 & 4 & 44 & 18 & 24 & - & -- \\
\hline 21 & 27 & 3 & 33 & 16 & 22 & 7 & 18 \\
\hline -- & - & -- & -- & 1 & 1 & 16 & 41 \\
\hline -- & $\cdots$ & -- & - & 21 & 28 & 1 & 3 \\
\hline
\end{tabular}

(a) Because of the passlbility for "other" responses these wll not necessarlly add to 100 percent. 
TABLE 4.10. Initial Major Concerns of Conservation Measure Adopters

\begin{tabular}{|c|c|c|c|c|c|c|}
\hline \multirow[b]{3}{*}{ Inltlal Major Concern } & \multicolumn{6}{|c|}{ Conservation Measure Adopted } \\
\hline & \multicolumn{2}{|c|}{$\begin{array}{l}\text { Low Pressure } \\
\text { on Center-Plvot }\end{array}$} & \multicolumn{2}{|c|}{$\begin{array}{l}\text { Low Pressure on } \\
\text { Handmove/Sideroll } \\
\end{array}$} & \multicolumn{2}{|c|}{$\begin{array}{l}\text { Systemaftc } \\
\text { Scheduling }\end{array}$} \\
\hline & Number & Percent (a) & Number & Percent (a) & Number & Percent ${ }^{(3)}$ \\
\hline $\begin{array}{l}\text { Energy Savlngs would not be } \\
\text { Large Enough }\end{array}$ & 5 & 6 & 2 & 22 & 4 & 10 \\
\hline $\begin{array}{l}\text { Water Coverage would not be } \\
\text { Good Enough }\end{array}$ & 16 & 20 & 2 & 22 & 3 & 8 \\
\hline Increased Labor Costs & -- & -- & - & -- & 1 & 3 \\
\hline Excessive Runoff Problems & 24 & 30 & -- & - & -- & -- \\
\hline None & 33 & 42 & 5 & 56 & 8 & 21 \\
\hline
\end{tabular}

(a) Because of the possibility for "other" responses these will not necessarlly add to 100 percent.

Table 4.9 indicates that although published magazines were frequent ly cited as an initial source of information, they were usually not enough to convince irrigators to adopt conservation measures. In most cases, interactions with either irrigation equipment/utility representatives or other farmers were necessary in order for conservation measures to be adopted. This was particularly true for the small number of adopters of low-pressure irrigation on handmove/sideroll systems, where only 1 of the 5 irrigators who first learned of low-pressure in published magazines reported adopting low-pressure on the basis of this information. Irrigation consultants appeared to be particularly important to the adoption of systematic irrigation scheduling methods.

The major initial concern of adopters (Table 4.10) of low-pressure irrigation on center-pivot systems was that excessive runoff problems would occur. However, responses to the telephone survey indicated that runoff was not found to be a problem for over $95 \%$ of adopters of $10 w$-pressure on centerpivot systems. Thus, while excessive runoff is often perceived to be a barrier to the adoption of low-pressure irrigation, it is likely that word-of-mouth concerning the successful experiences of irrigators with low-pressure will eventually overcome this barrier.

The largest single category of responses concerning the initial concerns of conservation measure adoptors was "none" or "no major concerns" for all 
three conservation measures. Thus, it appears that the interactions with irrigation equipment/utility representatives and irrigation consultants were relatively successful in reducing the concerns of measure adopters. Among the small number of irrigators adopting either low-pressure on handmove/sideroll or systematic scheduling, concerns about energy savings levels and water coverage were predominant.

\subsection{QUESTION 3}

Where did irrigators adopting conservation measures obtain financing for measure purchase and installation, how difficult was it for them to obtain such financing, and how important are financing constraints in limiting conservation actions by irrigators relative to other factors?

\subsubsection{Approach to Question 3}

In order to address Question 3, results from the following in-person survey questions were used:

IPQ.174

Where did you obtain financing for your investment in low-pressure (on center-pivot)?

IPQ. 175

How difficult was it for you to obtain equipment

financing for your investment in low-pressure from your financing source?

IPQ.179-182 Please rate each of the following factors in terms of their importance about why you currently don't have lowpressure equipment on your center-pivot system:

1. Would like to install low-pressure equipment, but can't get financing.

2. Low-pressure equipment would not adequately irrigate my crops.

3. Savings on energy costs at current prices wouldn't justify installation costs.

4. The use of low-pressure would increase my labor and maintenance costs. 
IPQ.187

IPQ .188

IPQ.198-IPQ.201 their importance about why you currently don't have lowpressure equipment on your handmove/sideroll system:

1. Can't get financing.

2. Would not adequately irrigate my crops (would leave dry spots).

3. Savings on energy costs wouldn't justify installation costs.

4. Low-pressure equipment would increase my labor and maintenance costs.

IPQ.205

IPQ.206

Where did you obtain financing for your investment in a larger mainline?

How difficult was it for you to obtain financing for your investment in a larger mainline from your financing source?

IPQ.209-IPQ.210 Please rate each of the following factors in terms of their importance about why you have not installed larger mainlines:

1. Can't get financing?

2. Don't believe the energy savings would justify its purchase and installation?

\subsubsection{Results}

Results pertaining to Question 3 are shown in Tabies 4.11 to 4.13 . Note that most of the financing of conservation investments was provided by either normal farm lending sources (banks, production credit associations, etc.) or 
TABLE 4.11. Sources of Financing for Irrigator Investments in Conservation Measures

\begin{tabular}{|c|c|c|c|c|c|c|c|c|}
\hline \multirow[b]{2}{*}{ Flnancing Source } & \multicolumn{2}{|c|}{$\begin{array}{l}\text { Con-Pressure } \\
\text { on Center-Pivot }\end{array}$} & \multicolumn{2}{|c|}{$\begin{array}{l}\text { Low-Pressure } \\
\text { on Handmove/Sideroll }\end{array}$} & \multicolumn{2}{|c|}{$\begin{array}{l}\text { MainTine } \\
\text { Modif Ication }\end{array}$} & \multicolumn{2}{|c|}{$\begin{array}{l}\text { Systematle } \\
\text { Scheduling }\end{array}$} \\
\hline & Number & Percent & Number & Percent & Númber & Percent & Number & Percent \\
\hline Normal Farm Lending Sources & 37 & 47 & -- & -- & 32 & 43 & 7 & 18 \\
\hline Internal farm Sources & 31 & 39 & 9 & 100 & 39 & 53 & 20 & 51 \\
\hline Cost Sharing With Utllity & 1 & 1 & -- & $\rightarrow$ & $\rightarrow$ & -- & - & - \\
\hline Leased From Equipment Dealer & 3 & 4 & -- & -- & -- & $\cdots$ & -- & - \\
\hline Department of water Resources & 2 & 3 & $\cdots$ & - & 1 & 1 & -- & - \\
\hline Cost Share with SCS & $\ldots$ & $\ldots$ & - & - & 4 & 5 & - & - \\
\hline
\end{tabular}

TABLE 4.12. Perceived Difficulty of Obtaining Financing for Conservation Measure Purchase and Installation

\begin{tabular}{|c|c|c|c|c|c|c|c|c|}
\hline \multirow[b]{3}{*}{ Diffliculty In ObtalnIng Flnancing } & \multicolumn{8}{|c|}{ Conservation Measure Adopted } \\
\hline & \multicolumn{2}{|c|}{$\begin{array}{l}\text { Low-Pressure } \\
\text { on Center-Pivot }\end{array}$} & \multicolumn{2}{|c|}{$\begin{array}{l}\text { Low-Pressure } \\
\text { on Handmove/Siderol, }\end{array}$} & \multicolumn{2}{|c|}{$\begin{array}{l}\text { Malnifne } \\
\text { Modification }\end{array}$} & \multicolumn{2}{|c|}{$\begin{array}{l}\text { Systematic } \\
\text { Scheduling }\end{array}$} \\
\hline & Number & Percent & Number & Percent & Number & Percent & Number & Percent \\
\hline Not at alf Difflcult & 46 & 58 & 5 & 56 & 47 & 64 & 19 & 49 \\
\hline Slightly Difflcult & 16 & 20 & 1 & 11 & 8 & 11 & 5 & 13 \\
\hline Moderotely Difficult & 7 & 9 & 1 & 11 & 10 & 14 & - & -- \\
\hline Very DIfflcult & 3 & 4 & -- & -- & 2 & 3 & 1 & 3 \\
\hline
\end{tabular}


TABLE 4.13 Rated Importance ${ }^{(a)}$ of Various Factors in Limiting Conservation Investments by Non-Adopters of Conservation Measures

\begin{tabular}{|c|c|c|c|c|}
\hline \multirow{2}{*}{ Factor } & \multicolumn{4}{|c|}{ Conservation Measure Adopted } \\
\hline & $\begin{array}{l}\text { Lan-Pressure } \\
\text { on Center-Pivot }\end{array}$ & $\begin{array}{l}\text { Lon-Pressure } \\
\text { on Handmove/Sideroll }\end{array}$ & $\begin{array}{l}\text { MaTn Tine } \\
\text { Modiflcation }\end{array}$ & $\begin{array}{l}\text { Systemafic } \\
\text { Schedul Ing }\end{array}$ \\
\hline Can't ge $\uparrow$ Financing & 8.0 & 6.2 & 7.1 & NA \\
\hline Inadequate Crop IrrigatIon & 9.5 & 11.4 & NA & 7.4 \\
\hline Savings Wouldn't Justify Costs & 10.0 & 12.3 & 12.7 & 10.4 \\
\hline Increase Labor/Maintenance & 5.4 & 9.1 & NA & 9.9 \\
\hline
\end{tabular}

(a) Average rated importance on a scale of 1 to 16. 
internal farm sources. Internal farm sources were the predominant method of financing conservation measure investments for all measures except low-pressure on center-pivot.

Table 4.12 illustrates that obtaining financing for conservation measures was perceived to be "not at all difficult" or "slightly difficult" by the majority of adopters of conservation measures of at1 types. The response of "not at all difficult" was by far the most frequent response for all conservation measure types.

Table 4.13 indicates that the major impediments to conservation measure investments by non-adopters of conservation measures were felt to be a lack of cost-effectiveness for such investments and concerns about inadequate crop irrigation. These beliefs were particulariy strong among non-adopters of lowpressure on handmove/sideroll systems. Concerns about "increased labor/maintenance" were found to be relatively important only for systematic scheduling methods. Financing constraints were generally rated lower than other factors in terms of their importance in limiting conservation investments.

The implications of the results presented in this section are that financial constraints were not perceived to be a particularly important factor in limiting conservation investments by irrigators at the time of the survey. This suggests that limited Bonneville resources may more effectively be used for education/demonstration programs than for cost-sharing programs. The results of the survey suggest that if irrigators can be convinced of the benefits of undertaking conservation investments, they generally will be able to find a means of financing such investments.

\subsection{QUESTION 4}

How aware of the possibility of undertaking conservation actions are those irrigators who have not taken conservation actions and what would be necessary to convince them to undertake conservation actions? 


\subsubsection{Approach to Question 4}

In order to answer Question 4, results from the following in-person survey question were used:

IPQ.128-IPQ.136 Have you had any opportunity to become familiar with any of the following methods of potentially reducing your energy used for irrigation or not?

- Low-pressure irrigation on center-pivot

- Low-pressure irrigation on sideroll/handmove

- Larger mainlines

- Improved fittings design

- Methods to improve pump efficiency

- Methods to measure soil moisture other than by touch

- Irrigation scheduling services

- Methods for scheduling irrigation applications other than by rule of thumb or experience

- Variable speed pump

IPQ. 183 What would be necessary to convince you to try lowpressure irrigation on your center-pivot system?

IPQ.202 What would be necessary to convince you to try lowpressure irrigation on your handmove/sideroll system?

IPQ.211 What would be necessary to convince you to install larger mainlines?

$I P Q .228$ What would be necessary to convince you to try one of these systematic scheduling methods?

\subsubsection{Results}

Results shown in Tables 4.14 and 4.15 indicate that wide variation exists in irrigator awareness of various conservation measures. The conservation measure of low-pressure on center-pivot systems appears to be known to the majority of irrigators in all geographic and usage classifications except GStratum 4 (Yakima Valley) and over 80 percent of all respondents stated they were aware of this measure. In contrast, awareness concerning the potential 
TABLE 4.14. Percentages on In-Person Survey Respondents Who Were Aware of Various Methods of Reducing Energy Used in Irrigation by G-Strata

\begin{tabular}{|c|c|c|c|c|c|c|c|c|}
\hline \multirow[b]{2}{*}{ Conservation Method } & \multicolumn{8}{|c|}{ G-Strata } \\
\hline & 1 & 2 & 3 & 4 & 5 & 6 & 7 & A11 G-Strata \\
\hline $\begin{array}{l}\text { Low-Pressure on } \\
\text { Center-Pivot }\end{array}$ & 100 & 88 & 98 & 31 & 62 & 73 & 78 & 83 \\
\hline $\begin{array}{l}\text { Low-Pressure on } \\
\text { Handmove/Sideroll }\end{array}$ & 71 & 57 & 58 & 23 & 44 & 66 & 61 & 50 \\
\hline Larger Mainlines & 67 & 86 & 91 & 82 & 88 & 73 & 78 & 84 \\
\hline $\begin{array}{l}\text { Improved Fitting } \\
\text { Design }\end{array}$ & 76 & 76 & 83 & 47 & 64 & 73 & 66 & 73 \\
\hline $\begin{array}{l}\text { Methods to Improve } \\
\text { Pump Efficiency }\end{array}$ & 90 & 73 & 83 & 58 & 76 & 40 & 77 & 76 \\
\hline $\begin{array}{l}\text { Methods to Measure } \\
\text { Soil Moisture Other } \\
\text { than by Touch }\end{array}$ & 80 & 81 & 88 & 58 & 76 & 80 & 61 & 78 \\
\hline $\begin{array}{l}\text { Irrigation Scheduling } \\
\text { Services }\end{array}$ & 80 & 63 & 83 & 47 & 64 & 46 & 44 & 64 \\
\hline $\begin{array}{l}\text { Methods for Scheduling } \\
\text { Irrigations Other than } \\
\text { by Rule of Thumb or } \\
\text { Experience }\end{array}$ & 76 & 60 & 79 & 41 & 44 & 46 & 46 & 60 \\
\hline Variable Speed Pump & 52 & 50 & 63 & 24 & 16 & 33 & 33 & 45 \\
\hline $\begin{array}{l}\text { Average for all } \\
\text { Measures }\end{array}$ & 77 & 71 & 81 & 46 & 59 & 59 & 60 & 66 \\
\hline
\end{tabular}

use of low-pressure on handmove/siderol? systems was much lower with only 56 percent of all respondents stating they were aware of this measure. Using larger maintines to save energy was also well known among respondents, while systematic scheduling methods and variable speed pumps were much less known.

Overall awareness of the various types of conservation measures was highest in G-Stratum 3 (North-Central Oregon) and G-Stratum 1 (Southern Idaho). Awareness was lowest in G-Stratum 4 (Yakima Valley.) Information provided in 
TABLE 4.15. Percentages of In-Person Survey Respondents who Were Aware of Various Methods of Energy Used in Irrigation by U-Strata

\begin{tabular}{|c|c|c|c|c|c|c|}
\hline \multirow[b]{2}{*}{ Conservation Method } & \multicolumn{6}{|c|}{ U-Strata } \\
\hline & 2 & 3 & 4 & 5 & 6 & All G-Strata \\
\hline $\begin{array}{l}\text { Low-Pressure on } \\
\text { Center-Pivot }\end{array}$ & 63 & 81 & 64 & 85 & 93 & 83 \\
\hline $\begin{array}{l}\text { Low-Pressure on } \\
\text { Handmove/Siderol1 }\end{array}$ & 43 & 50 & 61 & 58 & 61 & 56 \\
\hline Larger Mainlines & 76 & 90 & 83 & 83 & 86 & 84 \\
\hline $\begin{array}{l}\text { Improved Fittings } \\
\text { Design }\end{array}$ & 57 & 72 & 62 & 87 & 91 & 73 \\
\hline $\begin{array}{l}\text { Methods to Improve } \\
\text { Pump Efficiency }\end{array}$ & 69 & 70 & 68 & 75 & 84 & 76 \\
\hline $\begin{array}{l}\text { Methods to Measure } \\
\text { Soil Moisture Other } \\
\text { than by Touch }\end{array}$ & 69 & 82 & 75 & 83 & 81 & 78 \\
\hline $\begin{array}{l}\text { Irrigation Scheduling } \\
\text { Services }\end{array}$ & 53 & 57 & 58 & 58 & 76 & 64 \\
\hline $\begin{array}{l}\text { Methods for Scheduling } \\
\text { Irrigations Other than } \\
\text { by Rule of Thumb or } \\
\text { Experience }\end{array}$ & 53 & 57 & 44 & 50 & 72 & 60 \\
\hline Variable Speed Pump & 44 & 32 & 34 & 33 & 56 & 45 \\
\hline $\begin{array}{l}\text { Average for all } \\
\text { Measures }\end{array}$ & 59 & 66 & 61 & 68 & 78 & 66 \\
\hline
\end{tabular}

Table 4.15 indicates that large farmers in U-Stratum 6 are the most aware of the various types of conservation measures, while small farmers in U-Stratum 2 are least aware.

As indicated in Table 4.16, a significant proportion of the non-adopters of conservation measures indicated that nothing could convince them to try these measures. This was particularly true for low-pressure on handmove/ sideroll systems and systematic irrigation scheduling, illustrating that a substantial amount of resistance to the use of these conservation measures is present. Recommendations and demonstrations by other farmers were found to be 
TABLE 4.16. Number and Percentage(a) of Conservation Measure Non-Adopters Who Could be Convinced to Try Conservation Measures by Various Methods

\begin{tabular}{|c|c|c|c|c|c|c|c|c|}
\hline \multirow{3}{*}{$\begin{array}{c}\text { Could be Convinced } \\
\text { to Adopt by }\end{array}$} & \multicolumn{8}{|c|}{ Conservation Measure } \\
\hline & \multicolumn{2}{|c|}{$\begin{array}{l}\text { Low-Pressue } \\
\text { on Center-PIvat }\end{array}$} & \multicolumn{2}{|c|}{$\begin{array}{l}\text { Low-Pressure on } \\
\text { Handmove/Si derol! }\end{array}$} & \multicolumn{2}{|c|}{ Madifl lcation } & \multicolumn{2}{|c|}{$\begin{array}{l}\text { Systematic } \\
\text { Schedulling }\end{array}$} \\
\hline & Number & Percent & Number & Percent & Number & Percent & Number & Percent \\
\hline $\begin{array}{l}\text { Informatlon In } \\
\text { Magazines }\end{array}$ & 1 & 2 & 7 & 4 & 3 & 2 & 3 & 1 \\
\hline $\begin{array}{l}\text { Talking wth Irrlga- } \\
\text { †lon EquIpment/Utility } \\
\text { Representatives }\end{array}$ & 4 & 9 & 12 & 7 & 6 & 4 & 9 & 5 \\
\hline $\begin{array}{l}\text { Recommendat Ion/Demon- } \\
\text { stratIon by Another } \\
\text { Farmer }\end{array}$ & 3 & 7 & $\$ 7$ & 9 & 12 & 8 & 28 & 14 \\
\hline $\begin{array}{l}\text { irrigation System } \\
\text { Audit }\end{array}$ & 2 & 5 & 4 & 2 & 1 & 1 & - & -1 \\
\hline $\begin{array}{l}\text { Improved Financlal } \\
\text { Situation }\end{array}$ & 3 & 7 & 3 & 2 & 2 & $i$ & -- & $\rightarrow$ \\
\hline Nothing & 5 & 11 & 67 & 37 & 44 & 29 & 65 & 33 \\
\hline Don't Know/1t Depends & 13 & 30 & 38 & 21 & 38 & 25 & 49 & 25 \\
\hline $\begin{array}{l}\text { Raise HIgh-Value Crops } \\
\text { Like Potatoes }\end{array}$ & - & - & $=$ & - & - & -- & 3 & 1 \\
\hline
\end{tabular}

(a) Percentages ill not generally sum to 100 because of the presence of a stgnificant number of "other" responses.

the most effective method of convincing non-adopters to try conservation measures, followed by personal contact with irrigation equipment or utility representatives.

Information presented in this section illustrates that much can be done to improve the knowledge levels of irrigators concerning various types of conservation measures. Approximately 40 percent of in-person survey respondents indicated that they were not aware or aquainted with the conservation measures of low-pressure on handmove/sideroll systems and systematic scheduling methods. Increasing awareness of these measures could be a key element of facilitating adoption of these measures. Demonstration programs and personal contacts appear to be the most effective methods of facilitating adaption, although even if these methods are used, adoption by many irrigators may be slow. 


\subsection{QUESTION 5}

What is the relative importance of reducing energy costs to irrigators?

\subsubsection{Approach to Question 5}

In order to answer Question 5, results from the following in-person survey questions were used:

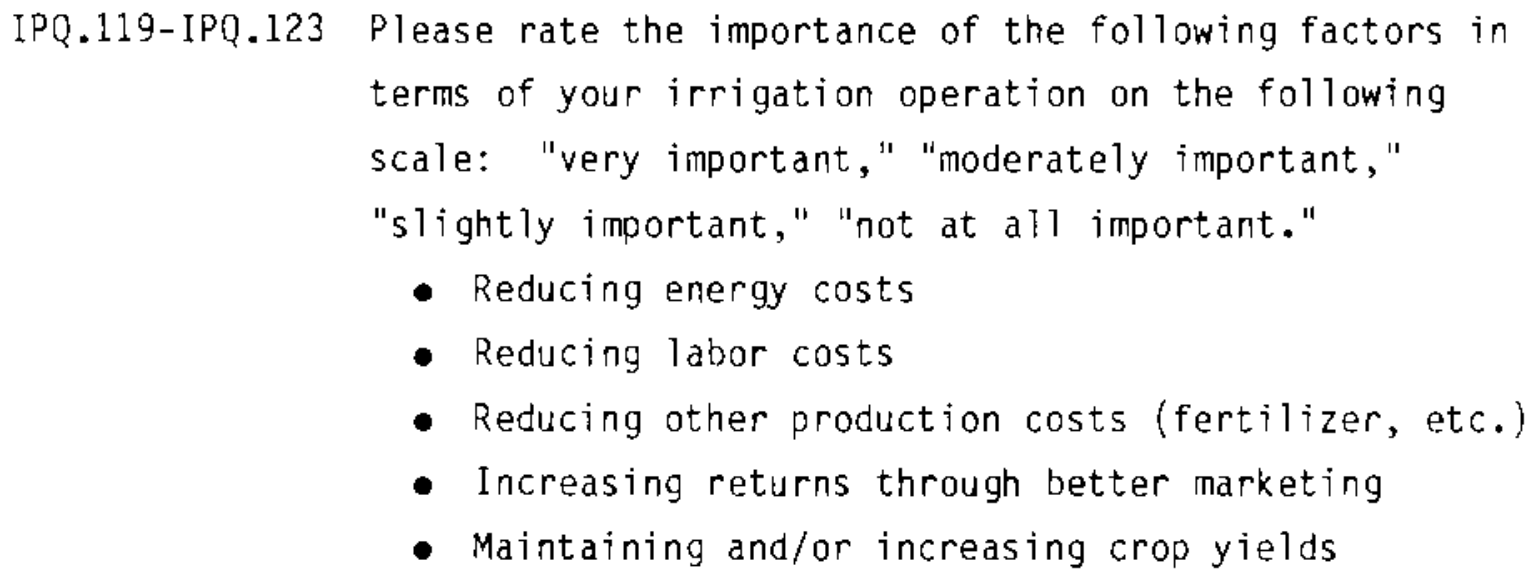

- Reducing energy costs

- Reducing labor costs

- Reducing other production costs (fertilizer, etc.)

- Increasing returns through better marketing

- Maintaining and/or increasing crop yields

As part of this question, respondents were asked to indicate the importance they placed on each of these factors by placing an $x$ on a continuous scale that was divided into four quadrants ranging from "not at all important" to "very important." This scale was later converted to a 16-point numeric score. Thus, it was possible to generate a numeric score for each factor's perceived importance, as well as a qualitative evaluation of its importance.

\section{5 .2 Results}

Results pertaining to the relative importance of energy costs to irrigators are shown in Tables 4.17 to 4.19. Note from Table 4.17 that "reducing energy costs" had the second highest percentage of in-person survey respondents rating it as "very important" and the highest percentage of respondents rating it as "moderately important." The combined percentage of respondents stating that reducing energy costs was either moderately or very important (88\%) trailed only the combined percentage for the factor of "maintaining and/or increasing crop yields."

The factor importance ratings shown in Tables 4.18 and 4.19 represent the mean importance ratings on the 16-point numeric scale. Note that the factor 
TABLE 4.17. Relative Importance of Energy Costs and Other Factors to Irrigators

\begin{tabular}{|c|c|c|c|c|}
\hline \multirow[b]{2}{*}{ Factor } & \multicolumn{4}{|c|}{ Percent of In-Person Survey Respondents (a) } \\
\hline & $\begin{array}{l}\text { Very } \\
\text { Important }\end{array}$ & $\begin{array}{l}\text { Moderately } \\
\text { Important }\end{array}$ & $\begin{array}{l}\text { Slightiy } \\
\text { Important }\end{array}$ & $\begin{array}{l}\text { Not at A11 } \\
\text { Important }\end{array}$ \\
\hline Reducing Energy Costs & 54 & 34 & 9 & 2 \\
\hline Reducing Labor Costs & 37 & 31 & 24 & 7 \\
\hline $\begin{array}{l}\text { Reducing Other Production } \\
\text { Costs }\end{array}$ & 47 & 34 & 13 & 5 \\
\hline $\begin{array}{l}\text { Increasing Returns Through } \\
\text { Better Marketing }\end{array}$ & 53 & 25 & 15 & 6 \\
\hline $\begin{array}{l}\text { Maintaining and/or Increas- } \\
\text { ing Crop Yields }\end{array}$ & 68 & 23 & 6 & 2 \\
\hline
\end{tabular}

(a) Total responses equaled 241 .

TABLE 4.18. Factor "Importance" Ratings by G-Stratum

\begin{tabular}{|c|c|c|c|c|c|c|c|c|}
\hline \multirow[b]{2}{*}{ Factor } & \multicolumn{7}{|c|}{ G-Stratum } & \multirow[b]{2}{*}{ Total } \\
\hline & 1 & 2 & 3 & 4 & 5 & 6 & 7 & \\
\hline Reducing Energy Costs & 13.6 & 13.3 & 13.3 & 12.6 & 15.0 & 15.0 & 14.7 & 13.7 \\
\hline Reducing Labor Costs & 10.2 & 12.0 & 9.6 & 9.8 & 11.1 & 13.5 & 12.2 & 11.3 \\
\hline $\begin{array}{l}\text { Reducing Other Production } \\
\text { Costs }\end{array}$ & 13.0 & 13.1 & 11.7 & 10.8 & 11.4 & 14.2 & 14.1 & 12.7 \\
\hline $\begin{array}{l}\text { Increasing Returns Through } \\
\text { Better Marketing }\end{array}$ & 14.5 & 13.0 & 11.8 & 12.5 & 12.3 & 14.5 & 12.9 & 12.9 \\
\hline $\begin{array}{l}\text { Maintaining and/or Increas- } \\
\text { ing Crop Yields }\end{array}$ & 13.9 & 15.1 & 14.8 & 13.7 & 14.1 & 15.2 & 15.3 & 14.8 \\
\hline All Factors & 13.0 & 13.3 & 12.2 & 11.9 & 12.8 & 14.5 & 13.8 & 13.1 \\
\hline
\end{tabular}

of "maintaining and/or increasing crop yields" was rated as being significantly more important than all other factors and "reducing labor costs" was rated as being much less important than other factors. By G-Strata, it appears that the factor "reducing energy costs" is relatively more important to respondents in 
TABLE 4.19. Factor "Importance" Rating by U-Stratum

\begin{tabular}{|c|c|c|c|c|c|c|}
\hline \multirow[b]{2}{*}{ Factor } & \multicolumn{5}{|c|}{ U-Stratum } & \multirow[b]{2}{*}{ Total } \\
\hline & 2 & 3 & 4 & 5 & 6 & \\
\hline Reducing Energy Costs & 12.9 & 13.3 & 14.6 & 13.8 & 13.8 & 13.7 \\
\hline Reducing Labor Costs & 10.8 & 10.6 & 12.0 & 10.8 & 11.6 & 11.3 \\
\hline $\begin{array}{l}\text { Reducing Other Production } \\
\text { Costs }\end{array}$ & 11.6 & 12.5 & 13.3 & 12.9 & 12.9 & 12.7 \\
\hline $\begin{array}{l}\text { Increasing Returns Through } \\
\text { Better Marketing }\end{array}$ & 12.3 & 12.7 & 12.4 & 13.0 & 13.4 & 12.9 \\
\hline $\begin{array}{l}\text { Maintaining and/or Increas- } \\
\text { ing Crop Yields }\end{array}$ & 13.3 & 15.4 & 14.8 & 14.1 & 15.4 & 14.8 \\
\hline All Factors & 12.2 & 12.9 & 13.4 & 12.9 & 13.4 & 13.1 \\
\hline
\end{tabular}

G-Stratum 5 (Southeastern Oregon) and G-Stratum 3 (North-Central Oregon). Reducing energy costs appears to be relatively less important to irrigators in G-Stratum 4 (Yakima Valley). No definite relationship between factor importance and irrigation load size (as indicated by U-Strata in Table 4.19) was noted, although all of the factors were rated as being relatively less important to the smaller irrigators in U-Stratum 2.

The results shown in Tables 4.17 to 4.19 indicate that reducing energy costs is regarded as an important priority by irrigators. Although these results may incorporate some respondent bias towards providing what would be considered a beneficial answer for Bonneville, it does appear that reducing energy costs is regarded as being at least of equal importance to most other methods of improving financial returns. It is particularly interesting to note that reducing energy costs received a significantly higher importance rating than reducing labor costs.

The fact that maintaining and/or increasing crop yields received by far the highest importance rating among the five factors indicates that crop yield levels are still of primary importance to farmers. Any conservation measure that is perceived to reduce yield levels (such as low-pressure sprinklers on handmove/sideroll systems) will likely have difficulty in gaining acceptance among irrigators. 


\subsection{QUESTION 6}

How satisfied are irrigators that have undertaken conservation actions on their own (i.e. outside of utility sponsored programs) with the energy savings and other benefits of these actions?

\subsubsection{Approach to Question 6}

Results from the telephone survey were utilized in addressing Question 6 because they provided a much larger set of observations than did the in-person survey. The following questions from the telephone survey were used:

T.Q.80 Which, if any, of the following changes have been made in your farm irrigation system since 1978?

- Added low-head sprinklers on center-pivot systems

- Added low-head sprinklers on handmove/siderolls

- Improved pump efficiency

- Installed larger mainlines

T.Q.118 Which changes are you dissatisfied with?

Responses to the questions listed above were separated into three groups 1) Stage I program participants, 2) all Stage I program non-participants, 3) Stage I program non-participants in public utilities. The percentages of conservation measure adopters expressing dissatisfaction with their conservation measure were then calculated for each group.

\section{6 .2 Results}

Results presented in Table 4.20 indicate that survey respondents are relatively well-satisfied with the conservation measures they have installed, irrespective of whether they had participated in the Stage I Program. Only 5 percent of the 244 respondents who reported adopting low-pressure on centerpivot outside of the Stage I Program expressed dissatisfaction with this conservation measure. Oniy 7 percent of the 153 adopters from public utilities who had not participated in Stage I expressed dissatisfaction. Expressions of dissatisfaction were even more infrequent for other types of measures.

The results presented in Table 4.20 appear to indicate that participation in the Stage I Program increased dissatisfaction with conservation measure 
TABLE 4.20. Percentages of Conservation Measure Adopters Expressing Dissatisfaction

\begin{tabular}{|c|c|c|c|}
\hline \multicolumn{4}{|c|}{ Group } \\
\hline $\begin{array}{l}\text { Conservation } \\
\text { Measure }\end{array}$ & $\begin{array}{l}\text { Stage I Program } \\
\text { Particlpants }\end{array}$ & $\begin{array}{l}\text { Al Stage I Program } \\
\text { Non-PartI cipant }\end{array}$ & $\begin{array}{l}\text { PubTic UfiTity SFage T } \\
\text { Program Non-Participant }\end{array}$ \\
\hline $\begin{array}{l}\text { Low-Pressure on } \\
\text { Center-Plyot }\end{array}$ & 14 & 5 & 7 \\
\hline $\begin{array}{l}\text { Low-Pressure on } \\
\text { Handmove/Sideroll }\end{array}$ & 0 & 0 & 0 \\
\hline $\begin{array}{l}\text { I mproved Pump } \\
\text { Eftlclency }\end{array}$ & 0 & 1 & 0 \\
\hline $\begin{array}{l}\text { Installed Larger } \\
\text { Malnlines }\end{array}$ & 7 & 1 & 2 \\
\hline
\end{tabular}

adoption. This result may be attributed as much to: 1) the relatively small number of Stage I participants in the survey and 2) the respondents' awareness that the survey was sponsored by Bonneville as it is related to any impacts of the Stage I Program. For example, only 4 of the Stage I Program respondents expressed dissatisfaction with low-pressure on center-pivot, but because only 28 of these respondents reported adopting this measure, reported dissatisfaction was relatively high at 14 percent. This level of dissatisfaction appears to be within tolerable limits. However, these results do support a conclusion that participation in a utility-sponsored program (such as Stage I) does not appear to increase the level of irrigators' satisfaction with conservation measure adoption.

\subsection{QUESTION 7}

How do Stage I Program participants compare to the general population of irrigators in terms of crop type, farm size and utility.

\subsubsection{Approach to Question 7}

In order to address Question 7, data from several sources were used. The oniy source of data on crop type and farm size for Stage I and the general population of irrigators was the telephone survey. The following questions from the telephone survey were used:

T.Q.3 Of the total acres you have in cropland, how many are set up for irrigation? 
T.Q.50 Which of the following types of irrigated crops were grown on your farm in 1985?

- Corn

- Wheat

- Potatoes

- Hay/Alfalfa

- Orchard Crops

- Others

- Barley

- Pastureland

Responses to these questions were segmented into Stage I and non-Stage I participant groups. Means and frequency distributions for the irrigated acres reported by these two groups were then developed. Frequency distributions by crop type were also derived.

Two sources of data were used to assess how Stage I Program participants compare to the general population in terms of utility. The first source of data was Bonneville records on the number of irrigation accounts for each utility in 1985. (a) These records are filed each year by utilities in the Bonneville service territory. The second data source was records from an irrigation system audit data base that PNL has compiled for Bonnevilie. This data base contains information on the utility district of the majority of irrigation system audits that have been conducted by BPA since the Stage I Program began. The market penetration of the Stage I Program was then estimated for all utilities with reported Stage I program participants.

\section{7 .2 Resuits}

Results that compare the crop mixes of Stage I versus non-Stage I Program participants are presented in Table 4.21. These results indicate that Stage I participants were more likely to have grown wheat and barley in 1985 and less likely to have grown orchard than non-Stage I participants. In general, it appears that growers of row crops other than wheat and barley are represented

\footnotetext{
(a) Unpublished data supplied by Cam Downing of Bonneville Power Administration.
} 
TABLE 4.21. Frequency Distribution of Crop Types by Stage I and Non-Stage I Program Participants

\begin{tabular}{|c|c|c|c|c|}
\hline \multirow[b]{2}{*}{ Crop } & \multicolumn{2}{|c|}{ Number } & \multicolumn{2}{|c|}{$\begin{array}{c}\text { Percent of Total } \\
\text { Respondents }\end{array}$} \\
\hline & Stage I & Non-Stage I & Stage & Non-Stage \\
\hline Corn & 20 & 179 & 21 & 16 \\
\hline Wheat & 68 & 524 & 72 & 46 \\
\hline Potatoes & 27 & 335 & 28 & 29 \\
\hline Hay/Alfalfa & 62 & 712 & 65 & 62 \\
\hline Orchard & 4 & 53 & 4 & 13 \\
\hline Others & 26 & 345 & 27 & 30 \\
\hline Barley & 39 & 347 & 41 & 30 \\
\hline Pasture & 23 & 241 & 24 & 21 \\
\hline
\end{tabular}

in the Stage I Program in similar proportions to non-Stage I participants. The under-representation of orchard growers in the Stage I Program is likely caused by the high proportion of irrigation loads served by private utilities and public utilities not served by Bonneville in the major orchard growing areas.

Information presented in Table 4.22 indicates that the Stage I Program has involved more farmers in the medium-size range of 700 to 2,000 acres than are

TABLE 4.22. Frequency Distributions and Means of Acres Under Irrigation by Stage I and Non-Stage I Program Participants

\begin{tabular}{|c|c|c|c|c|}
\hline \multirow[b]{2}{*}{ Acres } & \multicolumn{2}{|c|}{ Number } & \multicolumn{2}{|c|}{$\begin{array}{l}\text { Percent of Total } \\
\text { Respondents }\end{array}$} \\
\hline & Stage I & Non-Stage I & Stage I & Non-Stage \\
\hline $1-99$ & 3 & 333 & 3 & 19 \\
\hline $100-299$ & 14 & 213 & 15 & 19 \\
\hline $300-699$ & 22 & 268 & 23 & 23 \\
\hline $700-999$ & 23 & 109 & 24 & 9 \\
\hline $1,000-1,999$ & 17 & 194 & 18 & 17 \\
\hline $2,000-10,000$ & 16 & 137 & 17 & 12 \\
\hline Over 10,000 & 0 & 5 & 0 & .44 \\
\hline $\begin{array}{l}\text { Mean Number of Acres } \\
\text { Under Irrigation }\end{array}$ & 1,208 & 931 & NA & NA \\
\hline
\end{tabular}


represented in the non-Stage I respondents. In general, both the smallest and the largest farmers appear to be under-represented in the Stage I Program, a)though the mean number of acres under irrigation is about 300 acres higher for the Stage I Program participants. The higher representation of mediumsized farmers in the Stage I Program is a deliberate Bonneville strategy that appears is being achieved. However, this strategy has some significant implications including:

1. The percentage energy savings estimated for medium-sized Stage I Program participants may be higher than for the very large farmers not participating in the program.

2. The smaller farmers not participating in the Stage I program may never achieve the potential energy savings projected in the program because of a lack of economic incentives to realize such savings and/or the inability of Bonneville to cost-effectively induce such farmers to participate in the program.

Taken together, the fact that the Stage I Program tends to under-represent the smallest and the largest farmers indicates that the energy savings estimated from the Stage I Program shouid be extrapolated to the region on a conservative basis.

Estimates of the market penetration of the Stage I inspection program for all utilities reporting Stage I program participation and/or having irrigation loads exceeding 30,000 MWh are shown in Table 4.23. Note that estimated market penetration varies significantiy among the different utilities. Some of the utilities with large irrigation loads, such as Benton County PUD and Okanogan PUD, are not participating in the Stage I program, so reported penetration rates among their irrigators is consequently zero. However, several utilities that are participating in the Stage I program, including Grant County PUD, Harney Electric and Benton REA, had penetraton rates of less than 5 percent. Among all participating public utilities, the market penetration in 1986 was estimated to be 8.7 percent, while among all public utilities with significant irrigation loads, 1986 penetration was 7.2 percent. Approximately 1,600 audits are estimated to have been performed under the stage I program by the end of 1986. 
TABLE 4.23. Estimated Market Penetration of Stage I Program for Public Utilities With Loads Exceeding 30,000 MWh or With Reported Stage II Participants

\begin{tabular}{|c|c|c|c|c|c|c|c|c|c|}
\hline \multirow[b]{2}{*}{ Utility } & \multicolumn{3}{|c|}{1984} & \multicolumn{3}{|c|}{1985} & \multicolumn{3}{|c|}{1986} \\
\hline & Accounts (a) & Audits (b) & $\begin{array}{c}\text { Penetration } \\
\text { Percent } \\
\end{array}$ & Accounts & Audits & $\begin{array}{l}\text { Penetration } \\
\text { Percent }\end{array}$ & Accounts & Audits & $\begin{array}{c}\text { Penetration } \\
\text { Percent }\end{array}$ \\
\hline Benton REA & 1,817 & 18 & 1 & 1,808 & 38 & 2 & 1,830 & 51 & 3 \\
\hline Benton PUD & 792 & -- & $-\infty$ & 792 & $\rightarrow$ & -- & 828 & -- & -- \\
\hline Big Bend & 2,059 & 172 & 8 & 2,062 & 210 & 10 & 2,054 & 234 & 11 \\
\hline Central Electric & 1,024 & 22 & 2 & 1,059 & 44 & 4 & 1,088 & 89 & 8 \\
\hline Chelan PUD & 585 & -- & -- & 600 & -- & -- & 606 & -- & -- \\
\hline Columbia Basin & 258 & 22 & 9 & 228 & 22 & 10 & 220 & 41 & 19 \\
\hline Columbia REA & 506 & 35 & 7 & 492 & 50 & 10 & 491 & 67 & 14 \\
\hline Fall River & 4,449 & 13 & 14 & 449 & 36 & 8 & 231 & 36 & 16 \\
\hline Ferry County & 111 & 26 & 23 & 106 & 26 & 25 & 105 & 26 & 25 \\
\hline Flathead & 239 & - & -- & 240 & - & -- & 234 & 17 & 7 \\
\hline Franklin County & 780 & 69 & 9 & 793 & 84 & 11 & 799 & 127 & 16 \\
\hline Grant County & 3,531 & 23 & 1 & 3,593 & 23 & 1 & 3,601 & 23 & 1 \\
\hline Harney Electric & 1,307 & 24 & 2 & 1,299 & 26 & 2 & 1,294 & 45 & 3 \\
\hline Idaho Power Co. & 10,261 & -- & $\rightarrow-$ & 10,467 & 8 & .1 & 10,315 & 10 & .1 \\
\hline Lincoln Electric & 287 & 145 & 51 & 288 & 156 & 54 & 285 & 159 & 56 \\
\hline Lost River & 524 & 21 & 4 & 508 & 31 & 6 & 502 & 35 & 7 \\
\hline Lower Valley P\&L & 164 & -- & -- & 168 & -- & - & 171 & 7 & 4 \\
\hline Mid-State & 426 & 15 & 4 & 405 & 24 & 6 & 364 & 38 & 10 \\
\hline Northern Wasco & 44 & - & -- & 43 & -- & -- & 45 & 7 & 16 \\
\hline Okanogan PUD & 1,573 & -- & -- & 1,606 & -- & - & 1,450 & - & -- \\
\hline Raft River & 807 & 6 & 1 & 807 & 38 & 5 & 807 & 120 & 15 \\
\hline Ravalli & 563 & 50 & 9 & 557 & 95 & 17 & 538 & 96 & 18 \\
\hline Riverside Electric & 22 & -- & -- & 22 & -- & -- & 103 & 28 & 27 \\
\hline Rural Electric & 295 & $\ldots$ & -- & 306 & -- & -- & 302 & 14 & 5 \\
\hline Salmon River & 173 & 16 & 9 & 181 & 23 & 13 & 172 & 23 & 13 \\
\hline Southside Electric & 131 & -- & - & 134 & $\rightarrow$ & - & 152 & 6 & 4 \\
\hline Surprise Valley & 806 & $-\infty$ & -- & 785 & 13 & 2 & 741 & 26 & 4 \\
\hline Umatilla & 1,066 & 97 & 9 & 1,068 & 102 & 10 & 1,050 & 121 & 12 \\
\hline Unity & 123 & - & 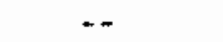 & 224 & 11 & 5 & 288 & 20 & 7 \\
\hline Vigilante & 784 & 72 & 9 & 790 & 125 & 16 & 797 & 125 & 16 \\
\hline Wells Electric & 85 & $\cdots$ & -- & 85 & -- & $-\infty$ & 88 & 18 & 20 \\
\hline Totals (c) & 25,331 & 846 & 3.3 & 21,498 & 1,178 & 5.5 & 21,236 & 1,599 & 7.2 \\
\hline Totals (d) & 22,381 & 846 & 3.8 & 18,500 & 1,178 & 6.4 & 18,352 & 1,599 & 8.7 \\
\hline
\end{tabular}

(a) Source: Unpublished data on the number of irrigation accounts in the peak month supplied by Cam Downing of Bonneville.

(b) Source: Cumulative audits compiled from Stage I inspection forms.

(c) Totals do not include accounts or audits from Idaho Power Company.

(d) Totals do not include accounts or audits from non-participating utilities or ldaho Power. 


\subsection{QUESTION 8}

How do Stage II Program participants compare to Stage I only program participants in terms of farm size, crop type and utility?

\subsubsection{Approach to Question 8}

Estimates of the farm sizes and crop types of Stage II program participants were obtained from data provided by a survey conducted as part of a Stage II program evaluation performed by PNL (Harrer, et al. 1987). These estimates may be somewhat incomplete because Stage II participants did not always provide data on ail of their irrigation systems. However, this data is the best available source of data on the farm sizes and crop types of stage 1 I program participants, and may be accurate enough to make reasonable comparisons of the characteristics of Stage II versus Stage I-only program participants.

The process of comparing the Stage II program participants to the Stage Ionly participants was begun by identifying the utilities, farm sizes and crop acres of each Stage II program participants that provided data as part of the Stage II program evaluation. Frequency distributions similar to those shown previously in Tables 4.21 to 4.23 were then generated as a basis for comparing Stage II program to Stage I-only program participants.

\subsubsection{Results}

Results comparing Stage II program to Stage I-only program participants are shown in Tables 4.24 to 4.26 . Note from Table 4.24 that the primary difference between the Stage II and Stage I-only program participants appears to be that Stage II program participants did not grow as much barley or wheat. This difference would not appear to be particularly important.

It appears from Table 4.25 that the estimated farm sizes of the Stage II program participants are smaller than those of the Stage I-only participants. This conclusion should be interpreted with caution, however, because the Stage II program participants did not always report all of their acres on the Stage II evaluation survey form. 
TABLE 4.24. Frequency Distribution of Crop Types by Stage II and Stage I-Only Program Participants

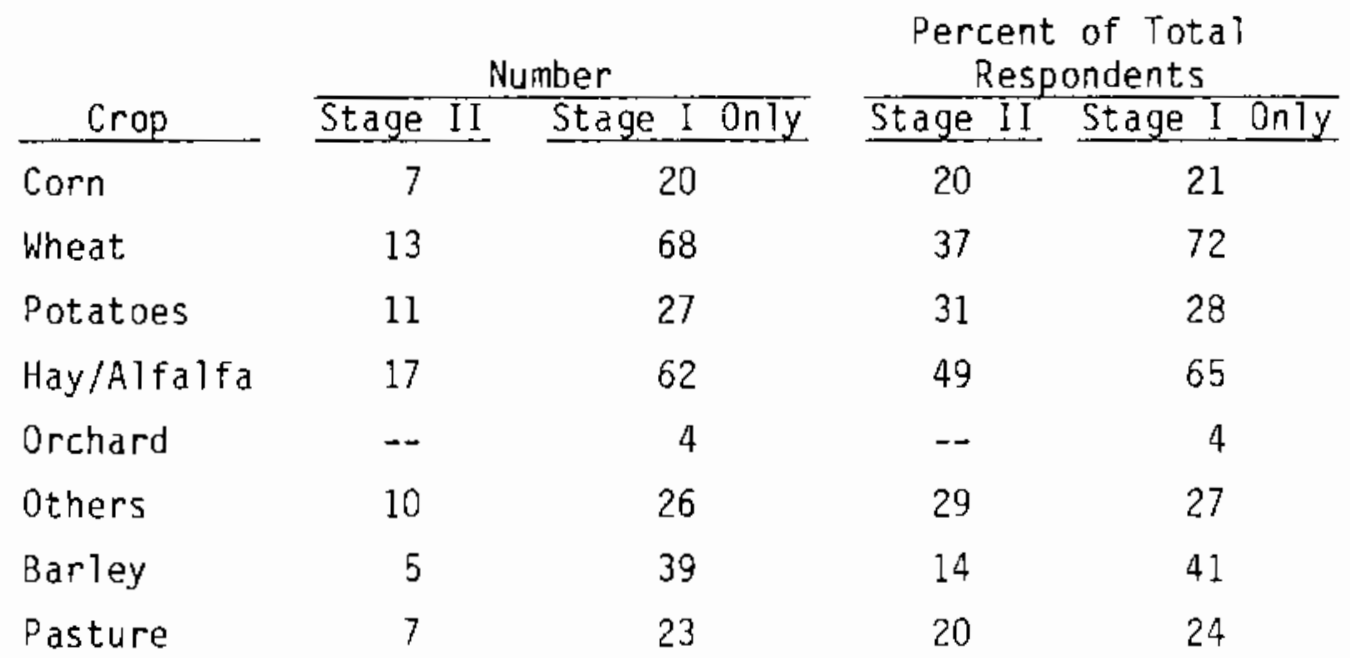

TABLE 4.25. Frequency Distributions and Means of Acres Under Irrigation by Stage II and Stage I-Only Program Participants

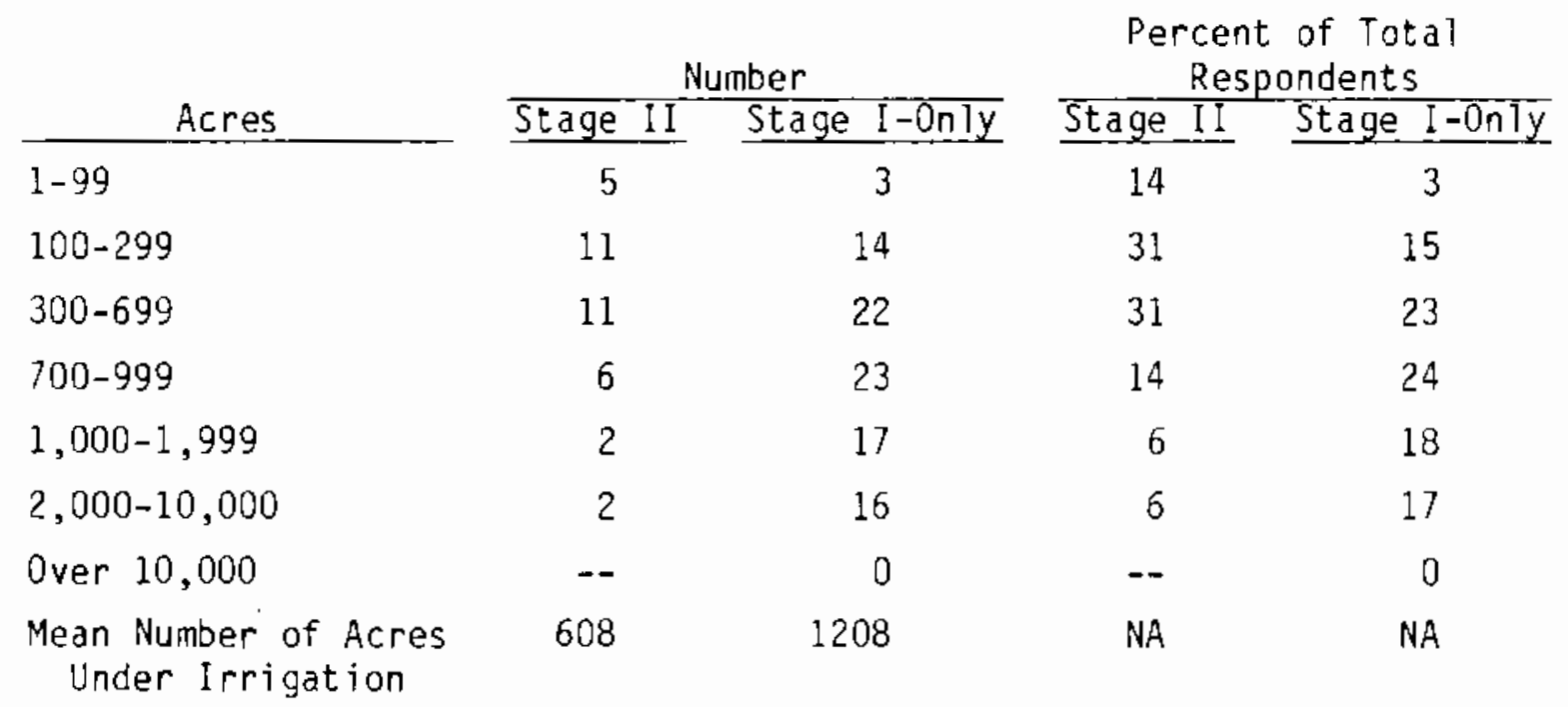

The most significant distinction between Stage II and Stage I-only program participants appears to be their utility district. Note from Table 4.26 that the penetration of the Stage II program varies significantly among utilities. Midstate Electric and Raft River had an extremely high percentage of Stage I participants from 1984 or before choosing to participate in Stage II by 1985. Umatilla Electric also had a relatively high participation rate. A number of 
TABLE 4.26. Estimated Penetration of Stage II Program at the End of 1984

\begin{tabular}{|c|c|c|c|}
\hline Utility & Stage II (1985) & Stage I (1984) & $\begin{array}{l}\text { Penetration } \\
\text { Percent }\end{array}$ \\
\hline Benton REA & 1 & 18 & 6 \\
\hline Big Bend & 23 & 172 & 13 \\
\hline Centrat Elec & 3 & 22 & 14 \\
\hline Columbia Basin & -- & 22 & -- \\
\hline Columbia REA & - & 35 & -- \\
\hline Fall River & -- & 13 & -- \\
\hline Ferry County & -- & 26 & -- \\
\hline Franklin County & 9 & 69 & 13 \\
\hline Grant County & $\cdots$ & 23 & -- \\
\hline Harney Electric & -- & 24 & $\cdots$ \\
\hline Lincoln Electric & 7 & 145 & 5 \\
\hline Lost River & -- & 21 & -- \\
\hline Midstate Electric & 17 & 24 & 71 \\
\hline Raft River & 3 & 6 & 50 \\
\hline Ravalli & -- & 50 & -- \\
\hline Salmon River & -- & 16 & -- \\
\hline Unatilla & 19 & 97 & 20 \\
\hline Vigilante & -- & 72 & -- \\
\hline
\end{tabular}

utilities with Stage I program participants had no Stage II program participants at the end of 1985. Two utilities with 50 or more Stage I program participants at the end of 1984 had no Stage II program participants as of the end of 1985 (Ravalli County Electric and Vigilante Electric). These results may well arise from a policy decision by utilities not to participate in and/or promote the Stage II program, but they indicate that the primary factor determining Stage II participation is an irrigator's utility district.

\subsection{QUESTION 9}

Identify by utility those irrigators that expressed dissatisfaction with irrigation scheduling. 


\subsubsection{Approach to Question 9}

In order to address Question 9, the following question from the telephone survey was used:

TQ.158 Which (irrigation scheduling) practice are you dissatisfied with?

- Use of checkbook balancing or other systematic irrigation scheduling program

- Use of a computerized irrigation scheduting program.

Frequency distributions of those providing responses to TQ. 158 were developed to address Question 9.

\section{9 .2 Results}

Results pertaining to Question 9 are shown in Table 4.27 . Note from Table 4.27 that over half of the respondents expressing dissatisfaction with irrigation scheduling are located in Southern Idaho utilities (Utah Power and Light, Raft River and Idaho Power Company). Apparently, some type of irrigation scheduling program was implemented in this region before 1985 which irrigators were unsatisfied with.

IABLE 4.27. Frequency Distribution of Dissatisfaction with Systematic Irrigation Scheduling Methods by Utility

\begin{tabular}{|c|c|c|}
\hline Utility & $\begin{array}{c}\text { Number } \\
\text { Dissatisfied }\end{array}$ & $\begin{array}{l}\text { Percent } \\
\text { of Total }\end{array}$ \\
\hline Franklin County PUD & 1 & 5.9 \\
\hline Pacific Power and Light & 1 & 5.9 \\
\hline Harney Electric Coop. & 2 & 11.8 \\
\hline Umatilla Electric & 1 & 5.9 \\
\hline Fall River Coop. & 1 & 5.9 \\
\hline Idaho Power Company & 1 & 5.9 \\
\hline Raft River Coop. & 3 & 17.6 \\
\hline Utah Power and Light & 5 & 29.4 \\
\hline
\end{tabular}




\subsection{QUESTION 10}

What types of crops were reported to be irrigated with low-pressure sprinklers on handmove/sideroll systems?

4.10.1 Approach to Question 10

The following questions from the telephone survey were used to address Question 10:

TQ.50 Which of the following types or irrigated crops were grown on your farm in 1985?

- Corn

- Wheat

- Potatoes

- Hay/alfalfa

- Any orchard crops

- Any others

- Barley

- Pastureland

TQ.80 Which, if any, of the following changes have been made in your irrigation system since 1985 ?

02 Added low-head sprinklers on handmove/sideroll systems?

A cross-tabulation of respondents reporting adoption of low-pressure on handmove/sideroll systems by crop type was performed to derive frequency distributions for addressing Question 10.

\subsubsection{Results}

Results pertaining to Question 10 are shown in Table 4.28. The primary crops grown by reported adopters of low-pressure on handmove/sideroll systems are hay/alfalfa, wheat and barley. This result is not surprising given that these crops are generally considered to be relatively non-water sensitive. More water sensitive crops, such as potatoes and orchard, had a lower reported incidence of low-pressure adoption. These results indicate that adoption of low-pressure on handmove/sideroll systems is more likely on relatively lowvalue, non-water sensitive crops than on high-value water sensitive crops. 
TABLE 4.28. Frequency Distribution of Crops Grown by Adopters of Low-Pressure on Handmove/Sideroll Systems

\begin{tabular}{lcc} 
Crop & $\begin{array}{c}\text { Number of } \\
\text { Growers }\end{array}$ & $\begin{array}{r}\text { Percent of } \\
\text { Total }\end{array}$ \\
\cline { 3 - 3 } Corn & 0 & 0 \\
Wheat & 18 & 26 \\
Potatoes & 7 & 10 \\
Hay/Alfalfa & 38 & 55 \\
Orchard & 2 & 3 \\
Other & 16 & 23 \\
Barley & 14 & 20 \\
Pasture & 7 & 10
\end{tabular}

\subsection{QUESTION 11}

What are the G-Strata, U-Strata and utility of irrigators reporting that they had developed more land since 1980 ?

\subsubsection{Approach to Question 11}

The characteristics of irrigators reporting that they had increased their irrigated acres between 1980 were described previously in Appendix $B$, Page B.14, of the Irrigation Customer Survey Procedures and Results study (Harrer, et al. 1987). G-Stratum 8 (Washington-0regon Coast) had the highest percent of respondents reporting they had increased irrigated acres since 1980 at $32 \%$ and the other G-Strata varied within a relatively narrow range of $10 \%$ to $19 \%$. The highest net percentage increase in irrigated acres, as reported on Page B.12 of Appendix B, in irrigated acres, as reported on Page $B .12$ of Appendix B, was $13 \%$ in G-Stratum 4 (Yakima Valley). Overa11, a 6\% net increase in total irrigated acres in the Pacific Northwest was found to have occurred between 1980 and 1985 .

It could not be directly determined how much of the reported increase in irrigated acres represented new acreage development, as opposed to the trading of existing irrigated land among farmers. Most of the respondents (59\%) reported "bought/rented more land" as the cause of their increased irrigated 
acres. However, 11\% of those reporting increased acres cited "converted/ developed more land" as the cause. Additional analyses were requested to characterize respondents stating that they had "converted/developed more land" between 1980 and 1985 .

The approach to addressing Question 11 utilized results from the following question:

TQ.16 What has caused you to increase the number of irrigated acres?

Cross-tabulations of respondents stating "converted/ developed more land" to this question were developed by G-Strata, U-Strata and utility.

\subsubsection{Results}

Results pertaining to Question 11 are shown in Tables 4.29 to 4.31. Vote from Table 4.29 that over half of those reporting converting/developing new land are located in the utilities of Pacific Power and Light, Utah Power and Harney Electric Cooperative. Table 4.30 indicates that most of the reported conversions/development of new land in 1980-1985 were located in G-Strata 5 (Southern Oregon) and G-Strata 1 (Southern Idaho). The larger farmers in

TABLE 4.29. Frequencies of respondents Reporting That They "Converted/ Developed More Land" Between 1980 and 1985 by Utility

\begin{tabular}{lccc}
\multicolumn{1}{c}{ Utility } & Frequency & & $\begin{array}{c}\text { Percent of } \\
\text { Total }\end{array}$ \\
\cline { 1 - 1 } Pacific Power & & 4 & 19 \\
Utah Power & & 4 & 19 \\
Harney Electric & & 19 \\
Benton County PuD & 3 & 14.3 \\
Idaho Power & 1 & 4.8 \\
Columbia Basin Electric & 1 & 4.8 \\
Surprise Valley Electric & 1 & 4.8 \\
East End Mutual & 1 & 4.8 \\
Kootenai Electric & 1 & 4.8 \\
Lost River Electric & 1 & 4.8
\end{tabular}


TABLE 4.30. Frequencies of Respondents Reporting That They "Converted/ Developed More Land" Between 1980 and 1985 by G-Strata

\begin{tabular}{|c|c|c|}
\hline G-Strata & Frequency & $\begin{array}{l}\text { Percent of } \\
\text { Total }\end{array}$ \\
\hline 1 & 6 & 28.6 \\
\hline 2 & 3 & 14.3 \\
\hline 3 & 1 & 4.8 \\
\hline 5 & 8 & 38.1 \\
\hline 7 & 2 & 9.5 \\
\hline 8 & 1 & 4.8 \\
\hline
\end{tabular}

TABLE 4.31. Frequencies of Respondents Reporting That They "Converted/ Developed More Land" Between 1980 and 1985 by U-Strata

\begin{tabular}{ccr} 
U-Strata & Frequency & $\begin{array}{r}\text { Percent of } \\
\text { Total }\end{array}$ \\
\cline { 2 - 3 } 1 & 2 & 9.5 \\
2 & 1 & 4.8 \\
3 & 3 & 14.8 \\
4 & 1 & 4.8 \\
5 & 5 & 23.8 \\
6 & 9 & 42.9
\end{tabular}

U-Strata 5 and 6 had more respondents reporting they had converted/developed more land than smaller farmers in other U-Strata (as indicated by results shown in Table 4.31).

\subsection{QUESTION 12}

What are the water source, pump lift, G-Strata, U-Strata and utility type of farmers indicating that they had decreased irrigated acres between 1980 and $1985 ?$

\subsubsection{Approach to Question 12}

In order to address Question 12, the following question from the telephone survey was utilized: 
TQ.13 Compared with 1980, has the total number of irrigated acres on the farm:

- increased

- decreased

- remained the same

A number of cross-tabulations were calculated to characterize respondents reporting decreases in irrigated acres between 1980 and 1985 .

\subsubsection{Results}

Results pertaining to Question 12 are shown in Tables 4.32 to 4.36 . Note from Table 4.32 that most of the irrigators reporting decreases in irrigated acres between 1980 and 1985 are served by public utilities.

The most interesting results pertaining to Question 12 are presented in Tables 4.33 and 4.34 . These resuits indicate that farmers using groundwater for irrigation are much more likely to have reported decreases in irrigated

TABLE 4.32. Frequency Distribution of Irrigators Reporting Decreases in Irrigated Acres by Utility Type

\begin{tabular}{ccc} 
Utility Type & Frequency & $\begin{array}{r}\text { Percent of } \\
\text { Total }\end{array}$ \\
\cline { 2 - 3 } & 12 & 20.7 \\
Public & 46 & 79.3
\end{tabular}

TABLE 4.33. Frequency Distribution of Irrigators Reporting Decreases in Irrigated Acres by Water Source

\begin{tabular}{lcr} 
Water Source (a) & Frequency & $\begin{array}{r}\text { Percent } \\
\text { Total }\end{array}$ \\
\cline { 3 - 3 } $\begin{array}{l}\text { Surface } \\
\text { Ground }\end{array}$ & 15 & 25.9 \\
Both & 29 & 50.0 \\
& 14 & 24.1 \\
(a) Represents farms using only surface \\
$\begin{array}{l}\text { water to irrigate, oniy groundwater to } \\
\text { irrigate, or both water sources to } \\
\text { irrigate. }\end{array}$
\end{tabular}


TABLE 4.34. Frequency Distribution of Irrigators Reporting Decreases in Irrigated Acres by Pump Lift

\begin{tabular}{lcr}
$\begin{array}{c}\text { Pump Ljft } \\
\text { (feet) }\end{array}$ & Frequency & $\begin{array}{r}\text { Percent of } \\
\text { Total }\end{array}$ \\
\hline $0-9$ & 5 & -9.3 \\
$10-24$ & 7 & 13.0 \\
$25-99$ & 6 & 11.1 \\
$100-299$ & 20 & 37.0 \\
$\geq 300$ & 16 & 29.6
\end{tabular}

(a) Represents reported acreage farm pumping lift.

TABLE 4.35. Frequency Distribution of Irrigators Reporting Decrease in Irrigated Acres by G-Strata

\begin{tabular}{ccc} 
G-Strata & Frequency & $\begin{array}{r}\text { Percent of } \\
\text { Total }\end{array}$ \\
\cline { 3 - 3 } 1 & 10 & 17.2 \\
2 & 23 & 39.7 \\
3 & 10 & 17.2 \\
4 & 5 & 8.6 \\
5 & 4 & 6.9 \\
6 & 2 & 3.4 \\
7 & 2 & 3.4 \\
8 & 2 & 3.4
\end{tabular}

acres than are farmers using surface water. In addition, information presented in Table 4.34 indicates that a strong positive relationship exists between farmers reporting decreases in irrigated acres and pumping 1 ifts. Over $65 \%$ of irrigators reporting decreases in irrigated acres between 1980 and 1985 were comprised of irrigators that reported average pumping lifts in excess of 100 feet.

As indicated in Table 4.35 , the majority of the irrigators reporting decreases in irrigated acres between 1980 and 1985 are located in G-Strata 1 (Southern Idaho), G-Strata 2 (Columbia Basin) and G-Strata 3 (North-Central 
TABLE 4.36. Frequency Distribution of Irrigators Reporting Decreases in Irrigated Acres by U-Strata

\begin{tabular}{|c|c|c|}
\hline U-Strata & Frequency & $\begin{array}{l}\text { Percent of } \\
\text { Total }\end{array}$ \\
\hline 1 & 4 & 6.9 \\
\hline 2 & 12 & 20.7 \\
\hline 3 & 5 & 8.6 \\
\hline 4 & 6 & 10.3 \\
\hline 5 & 10 & 17.2 \\
\hline 6 & 21 & 36.2 \\
\hline
\end{tabular}

Oregon). These areas have the largest irrigation loads in Bonneville's service area with both relatively high water demands and pumping lifts. There appeared to be no relationship between U-Strata and reported decreases in irrigated acres (Table 4.36), although U-Stratum 6 did have the largest number of irrigators reporting decreases in irrigated acres.

\subsection{QUESTION 13}

Do farmers perceive irrigated farming to be relatively more or less profitable than dryland farming?

\subsubsection{Approach to Question 13}

To address Question 13, results from the following in-person survey questions were used:

IPQ.229 Generally speaking, profits in agriculture are currently depressed. However, do you feel that profits from irrigated farming are:

- lower than those of dryland farming

- higher than those of dryland farming

- about the same as dryland farming

\subsection{3 .2 Results}

Results pertaining to Question 13 are presented in Tables 4.37 and 4.38 . Note from these results that over twice as many survey respondents believed 
TABLE 4.37. Views on Relative Profitability of Irrigated Farming (percent of respondents by U-Strata)

Relative Profitability of Irrigated Farming

Lower than Dryland

Higher than Dryiand

About the Same as

Dryland

Don't Know/No Idea

\begin{tabular}{|c|c|c|c|c|c|}
\hline \multicolumn{6}{|c|}{ U-Strata } \\
\hline 2 & 3 & 4 & 5 & 6 & Total \\
\hline 22 & 25 & 21 & 8 & 19 & 20 \\
\hline 49 & 48 & 52 & 50 & 36 & 44 \\
\hline 8 & 15 & 14 & 21 & 13 & 13 \\
\hline 20 & 13 & 14 & 21 & 31 & 23 \\
\hline
\end{tabular}

TABLE 4.38. Views on Relative Profitability of Irrigated Farming (percent of respondents by G-Strata)

Relative Profitability of Irrigated Farming

Lower than Dryland

\begin{tabular}{|c|c|c|c|c|c|c|c|}
\hline \multicolumn{8}{|c|}{ G-Strata } \\
\hline 1 & 2 & 3 & 4 & 5 & 6 & 7 & Tota \\
\hline 5 & 26 & 16 & 24 & 12 & 33 & 6 & 20 \\
\hline 14 & 45 & 49 & 29 & 56 & 27 & 72 & 44 \\
\hline 14 & 15 & 7 & 35 & -- & 27 & 6 & 13 \\
\hline
\end{tabular}

Higher than Dryland

$67 \quad 14 \quad 28$

12

32

$13 \quad 17$

23

that irrigated farming was more profitable than dryland farming compared to those believing that irrigated farming was less profitable than dryland farming. Views concerning the higher relative profitability of irrigated farming were most strongly held in G-Stratum 2 (Columbia Basin), G-Stratum 3 (North-Central Oregon), G-Stratum 5 (Southern Oregon) and G-Stratum 7 (Northern Idaho-Western Montana). These G-Strata comprise a large percentage of Bonneville's irrigation load. Larger farmers in U-Stratum 6 had the lowest percentage of respondents who viewed irrigated farming as more profitable than dryland farming.

Results presented in this section serve to reinforce findings from the telephone survey that widespread conversions from irrigated to dryland framing are neither feasible or likely under present conditions. The high investment costs of irrigation systems and the low degree of crop rotation flexibility associated with dryland farming limit the profitability of such conversions for most farmers. 


\subsection{QUESTION 14}

What crops do farmers perceive to be most profitable to grow in the future and how are present crop mixes likely to change?

\subsubsection{Approach to Question 14}

In order to address Question 14 results from the following in-person survey question were used:

When you are thinking about making cropping decisions or capital investments on your farm about how far in the future do you think?

IPQ.231-IPQ.238 Thinking that far ahead, please tell me, for each of these crops, if you think its profitability will be above average, average or below average over this time period:

- Corn

- Wheat

- Potatoes

- Hay

- Alfalfa

- Pastureland

- Barley

- Orchard Crops

IPQ.240-IPQ.247 What is your best guess of profitability of various crops five years from now? Again, for each, please tell me if you think its profitability will be above average, average or below average:

- Corn

- Wheat

- Potatoes

- Hay

- Alfalfa

- Pastureland

- Barley

- Orchard Crops 
IPQ.249-IPQ.259 Here's the cropping pattern you reported over the phone. What's your best guess as to the number of acres of each crop you' 11 be growing five years from now?

$$
\text { Past Season Five Years } \begin{aligned}
& \text { From Now } \\
& \hline
\end{aligned}
$$

Corn

Wheat

Potatoes

Hay

Alfalfa

Pastureland

Barley

Orchard Crops

Other

Total Irrigated Acres

Simple frequency counts were used to analyze the results of in-person survey questions 230 to 247 in relation to Question 4. However, in order to anaiyze changes in future crop mixes, it was necessary to compute the percentage changes in acreage mixes that farmers predicted in in-person survey questions 249 to 261. It was also necessary to consolidate the responses to these questions into the six crop categories used by Bonneville for irrigation sector load forecasting activities:

- Wheat

- Corn

- Hay/Alfalfa

- Potatoes

- Orchard

- Other

Finally, some obvious outliers in the crop acres predicted in five years were eliminated from the analysis. For, example one respondent who stated that he was planning to irrigate 10,000 acres of wheat five years from now, even though he reported that he is currently irrigating only 100 acres of wheat, was eliminated from the analysis pertaining to future crop mix. 


\subsubsection{Results}

The average time horizon for making cropping or capital investment decisions was found to be 4.6 years. Over 80 percent of survey respondents reported their time horizon as five years or less. Respondents' perceptions of the relative profitability of the various crops over their time horizons are presented in Table 4.39. Perceptions about crop profitability in five years are shown in Table 4.40 .

TABLE 4.39. Expected Profitability of Crops Over the Time Horizons Used by Irrigators in Making Cropping and Investment Decisions (in percent of survey respondents)

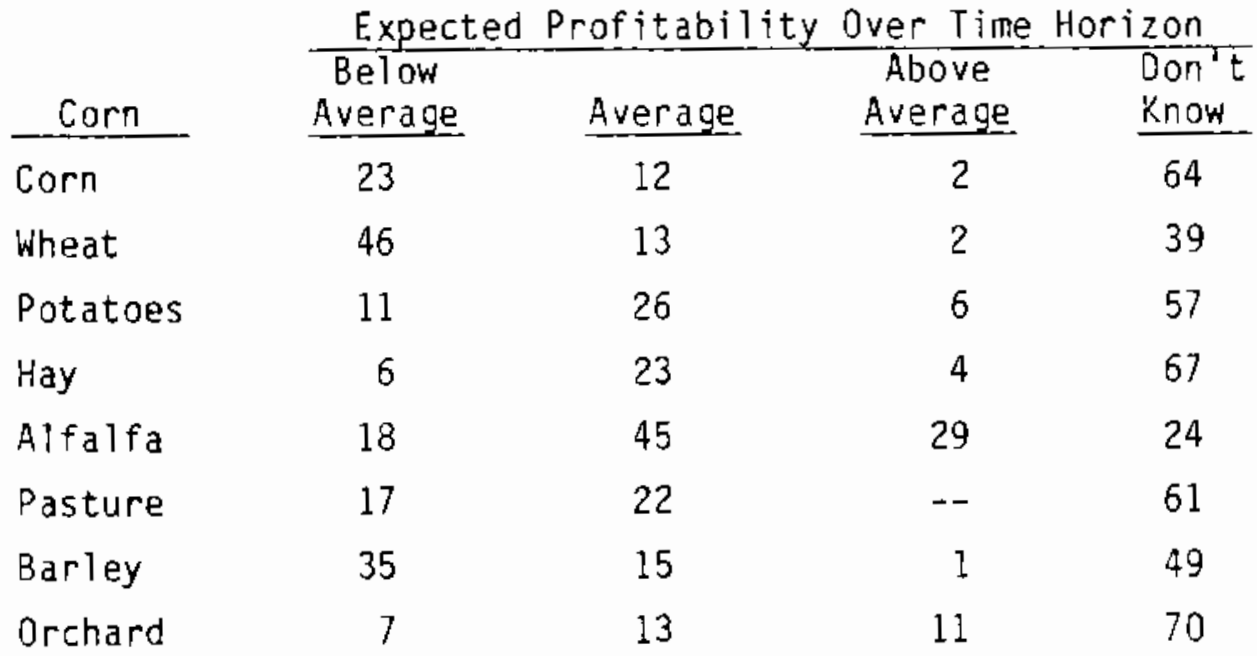

TABLE 4.40. Expected Profitability of Crops in Five Years

\begin{tabular}{|c|c|c|c|c|}
\hline Crop & $\begin{array}{l}\text { Below } \\
\text { Average }\end{array}$ & Average & $\begin{array}{c}\text { Above } \\
\text { Average }\end{array}$ & $\begin{array}{l}\text { Don't } \\
\text { Know }\end{array}$ \\
\hline Corn & 22 & 13 & 2 & 65 \\
\hline Wheat & 40 & 15 & 3 & 43 \\
\hline Potatoes & 10 & 25 & 7 & 59 \\
\hline Hay & 6 & 23 & 4 & 67 \\
\hline Alfalfa & 14 & 48 & 11 & 27 \\
\hline Pasture & 16 & 22 & - & 62 \\
\hline Barley & 31 & 16 & 2 & 51 \\
\hline Orchard & 7 & 13 & 11 & 70 \\
\hline
\end{tabular}


Many of the survey respondents were unwilling to venture a guess concerning the future profitability of the various crops. For those providing estimates, wheat and barley were generally perceived to have the lowest future profitability, while alfalfa and potatoes were perceived to have the highest future profitability. Orchard crops were also rated highly in terms of future profitability, although 70 percent of respondents did not venture a guess concerning the future profitability of orchard crops. For all crops, little differences in perceptions about future profitability were noted between respondents' time horizons (Table 4.39) and five years from now (Table 4.40).

Results presented in Table 4.41 indicate that respondents generally expect to decrease their irrigated acres of commodity crops (wheat and corn) and increase their irrigated acres in specialty crops (hay/alfalfa, orchard, other) over the next five years. Overail, a small decrease in total irrigated acres is anticipated by in-person survey respondents over the next five years.

TABLE 4.41. Expected Percentage Change in Mean Irrigated Crop Acres Over the Next Five Years by G-Strata

\begin{tabular}{|c|c|c|c|c|c|c|c|c|}
\hline \multirow[b]{2}{*}{ Crop } & \multicolumn{8}{|c|}{ G-Strata } \\
\hline & 1 & 2 & 3 & 4 & 5 & 6 & 7 & Total \\
\hline Wheat & -34 & -81 & +15 & -26 & -61 & -20 & +36 & -41 \\
\hline Corn & 0 & -5 & -22 & -23 & NA & NA & NA & -11 \\
\hline Potatoes & -17 & -3 & +1 & NA & -18 & 0 & +29 & +2 \\
\hline Alfalfa/Hay & -26 & +19 & +20 & +14 & +15 & +10 & +6 & +12 \\
\hline Orchard & NA & -1 & NA & +39 & NA & 0 & NA & +18 \\
\hline Other & +27 & NA & +18 & +5 & +30 & 0 & +8 & +26 \\
\hline All Irrigated Acres & -26 & -2 & 0 & -6 & -3 & -9 & NA & -4 \\
\hline
\end{tabular}




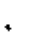




\section{REFERENCES}

Hair, J.F., Jr., R. E. Anderson, R. L. Tatham and B. J. Grablowsky. 1979. Multivariate Data Analysis. Petroleum Publishing Company, Tulsa, Oklahoma.

Harrer, B. J., J. W. Johnston, J. E. Dase, M. P. Hattrup, G. Reed. 1987. Irrigation Customer Survey Procedures and Results. PNL-6181. Pacific Northwest Laboratory, Richland, Washington.

Harrer, B. J., J. W. Tawil, A. J. Lyke, L. A. Nieves, E. S. Edin and B. M. Bailey. 1987. Empirical Evaluation of the Energy Savings Resulting from BPA's Stage II Irrigation System Retrofit Program. PNL-6160. Pacific Northwest Laboratory, Richland, Washington. 


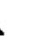




\section{APPENDIX A}

GUIDELINES AND DECISION RULES FOR

EOITING AND RESPONDENT CALLBACKS 
APPENDIX A

GUIDELINES AND DECISION RULES FOR

EOITING AND RESPONDENT CALLBACKS

The questionnaire number, ID number, G Strata, U Strata, and utilities should be the same as the telephone questionnaire. (In light of the transcription process, data from the telephone survey are viewed as correct in the event of inconsistencies.)

Q.1-4 OLD is information from the telephone questionnaire. REVISED is respondents' new answers, if different.

Q.5-23 If sections were missed that should have been asked, a callback was made, but only if callbacks were needed for another question.

Q.24-26 OLD is information from the telephone questionnaire. REVISED is respondents' new answers, if different. If the answer is 0 , this section was skipped.

Q.27 If 0.322 is "yes," Q.27 should be "no" and vice versa.

Q.28 If Q.323 has data, the same data applies to this question and vice versa.

Q.29-30 OLD is information from the telephone questionnaire. REVISED is respondents" new answer, if different. If answer is "no" surface water, this section was skipped.

Q.31-32 OLD is information from the telephone questionnaire. REVISED is respondents" new answer, is different. If answer is "no" ground water, this section was skipped.

Q.33-41 Answers from the telephone questionnaire filled in and the respondents' new answers were inserted under revised number of acres. 
Q.42-51 Answers from telephone questionnaire were filled in and Q.42-51 were asked for the appropriate systems. The beginning of the line pressure should be greater than at the sprinkler heads, except gravity flow or downhill gravity, and this was verified with NEA. Lowest acceptable pressure is 20 and average operating pressure should be between 40-80.

Q.52 A callback was made if the question was sxipped.

Q.53 The answer should be close to 0.2 (relative proportions).

Q.99 A callback was made if the question was skipped.

Q.109 A callback was made if the question was skipped.

Q.110-111 OLD is information from the telephone questionnaire. REVISED is the respondents" new answer, if different. If the answer from the telephone survey is "don't know," this section was skipped. Values greater than $80 \%$ in $Q .111$ were edited to $80 \%$.

Q.112 Data from the telephone survey were inserted. A callback was made if information varied between the telephone study and the in-person study. Documentation of the reasons for the variance was made (see margin comments).

Q.113-127 A callback was made if these questions were missed.

Q.128-136 "Yes" or "no" should be circled if not already taken (from telephone questionnaire). If question was missed, a callback was made only if a callback was required for another question. Q.137-145 If "experience" was noted at least once and other questions were left blank, "experience" was inserted in the blank questions; if all were blank, a non-response code was added.

Q.146-148 A callback was made only if another callback on questionnaire was needed. "Don't know/unsure" was circled if no other callback was made.

Q.149 A callback was made if the question was skipped. 
Q.150 A callback was made only if another callback on questionnaire was needed. "None applicable" was circled if a callback was not needed.

Q.151-159a A callback was made if these questions were skipped.

Q.159b-170 A callback was made if these questions were skipped.

Q.171-211 Box information was compared with pages 3, 7, and 8. (Changes made as result of callback from $Q .112$ would change Q.113-116 and possibiy . $171-211$. )

Q.183 A callback was made if this question was missed. Code 96 ("difficult to answer") was used if the question was inappropriate in 1 ight of the farmer's situation (see margin comments.)

Q.212-214 A callback was made if a question was skipped. In-person data was considered correct when comparing in-person to telephone questionnaire results.

Q.215-224 Callbacks were made if questions were skipped.

Q.225-228 Code 96 ("difficult to answer") was used if question was missed.

Q.229-230 Callbacks were made if questions were missed.

Q.231-239 Callbacks were made if missed completely. "Don't know" was circled if partially completed.

Q.240-248 Data transferred from Q.231-239 if question missed.

Q.248b-261 Telephone data inserted under PAST SEASON. $99994=$ increase but unsure of acreage, 99995 = decrease but unsure of acreage.

Q.262-285 A callback was made if questions were missed.

Q.288-289 A callback was made only if another callback in questionnaire was required. "Don't know" was used if no callback was made. 


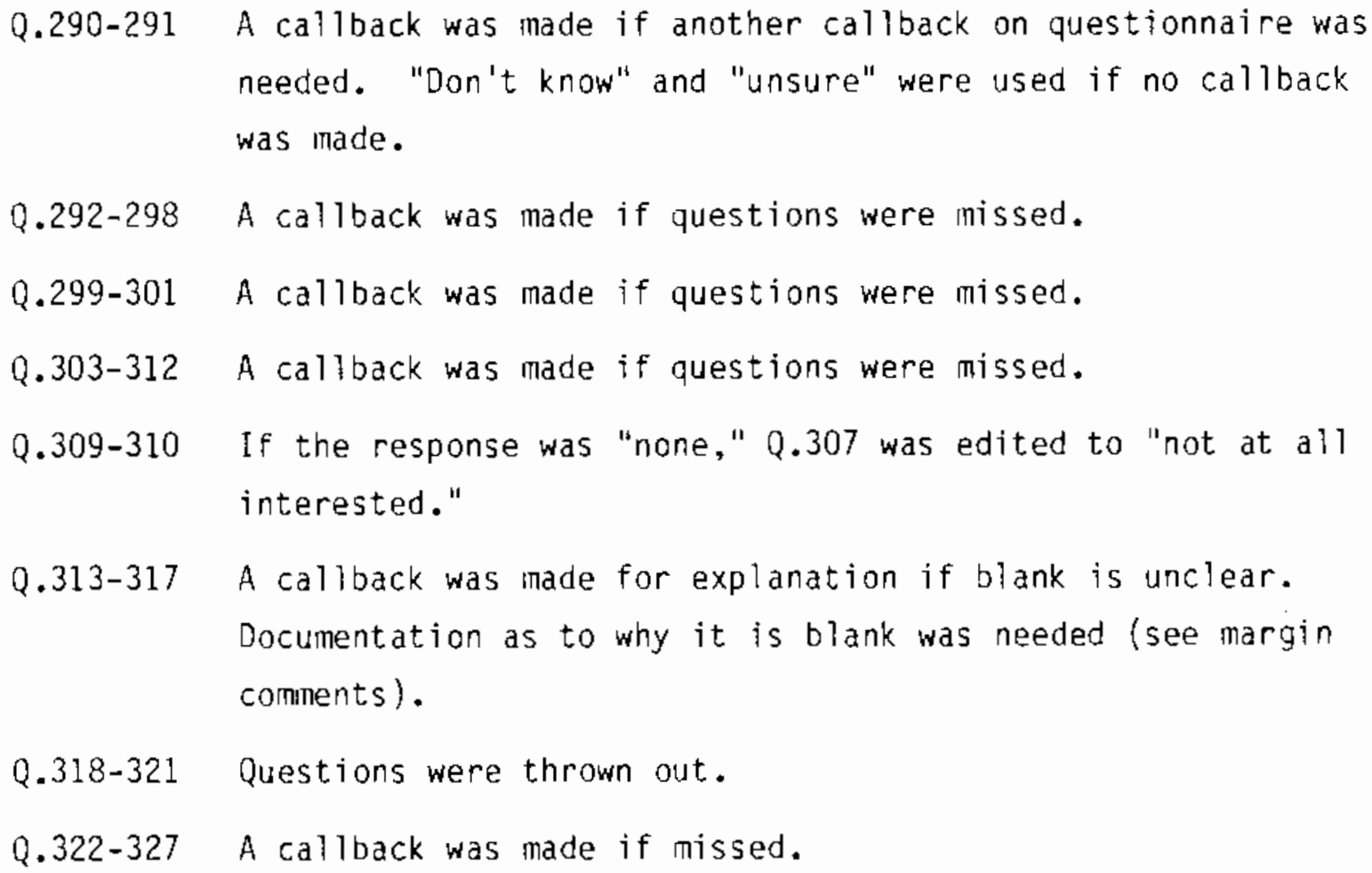




\section{DISTRIBUTION}

No. of

Copies

OFFSITE

30 DOE Technical Information Center

K. Keating

Bonneville Power Administration

P.0. Box 3621

Portland, $O R \quad 97208$

E. Westman

Bonneville Power Administration P.0. Box 3621

Portland, OR 97208

2 C. Hickman

Bonneville Power Administration P.0. Box 3621

Portland, OR 97208

F. Gordon

Bonneville Power Administration P.0. Box 3621

Portland, OR 97208

S. Levy

Bonneville Power Administration P.0. Box 3621

Portland, OR 97208
No. of

Copies

J. Wilkens

Bonneville Power Administration P.0. Box 3621

Portland, OR 97208

M. Corrigan

Department of Energy

Forrestal Building 1000 Independence Ave., S.W. Washingt on, DC 20585

ONSITE

DOE Richland Operations Office

J. J. Sutey

18 Pacific Northwest Laboratory

B. L. Mohler

M. P. Hattrup

J. W. Johnson

G. L. Wilfert

B. J. Harrer (6)

J. E. Dase

Publishing Coordination MH (2)

Technical Report Files (5) 


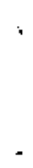

